本品は Chemische Fabrik Homburg A.-G. 設賣にかかる過酸化水素とカミッレ

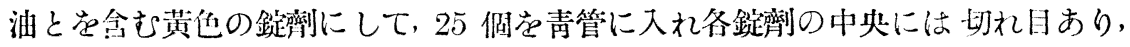
1 錠の重さ約 $0.55 \mathrm{~g}$ にしてカミッレ樣の微臭范推しアルカリ性のやくが如き味 あり，その $4.4 \%$ は水に泬け文又大部分は灰化せざるも植物成分は灰化方。本品 は試驗の結果次の如き組成夿行す,

過酸化ナトリウム

約 $15 \%$ 次亞燐酸ナトリウム

約 $25 \%$

滑 石 約 $3 \%$ 植物性粉末(カネツレなぞ) 約 $1,5 \%$

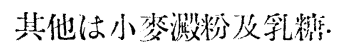

本品 1 鉹は $0.036 \mathrm{~g}$ ○ $\mathrm{H}_{2} \mathrm{O}_{2}$ に相賞市.

(渡部)

Cyclohexenylbarbitursäure の不正品 E. Rupp: Apoth. Ztg., 4S, 13 (1933) 著 者は Chiron, G. m. b. H., Berlin W 8 發䝴の本品觉武驗せるにフェナ七チン及び フェニールアリールバルビッール酸と賦形劑とより成る觉發見したり。（渡部）

\title{
VII. 藥品製造學
}

\section{N-置換 1,3-ヂアミノー2-プロパノール類の製造 Winthrop Chemical Co. Inc.,} New York, U. S. $\Lambda$., übert. von : Otto Eisleb, Hofheim i. Taunus. 米國特許

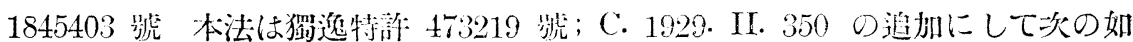

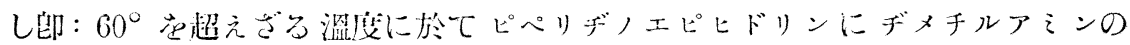

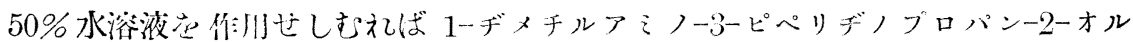

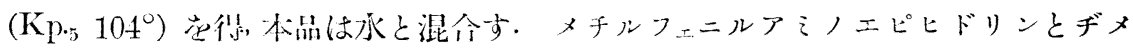
チルアネンとよりは1ーヂメチルアミノー3-フェニルメチルアミノプロパン-2-オル

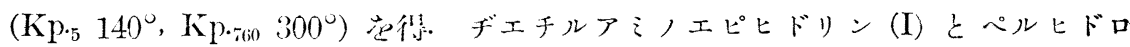
カルバッォールとよりは II なる化命物 $\left(\mathrm{Kp}_{11} 214^{\circ}\right)$ 芭得. 又 I と 6-メトオキ シー1.2,3,4-テトラヒドロイソヒノリンとよりは III (Kp· 195 ) 范得.（田中）
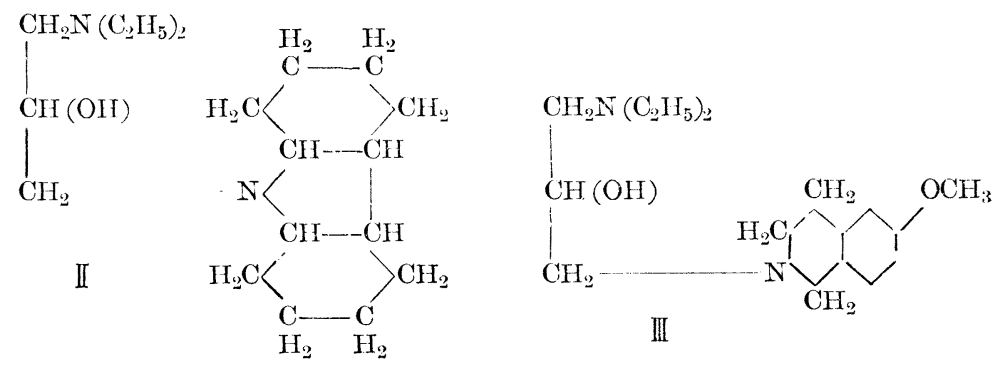
ペラルゴンアルデヒドの製法 Selden Co., Pittsburgh, übert. von：Alphons O. Jaeger, Mount Lebanon, und Lloyd C. Damiels, Craftor, Pennsylvania. U. S. A. 米國特許 1849834 號 セバチン酸覧類な水素及水蒸氭の存在に於て $300-450^{\circ}$ に 加熱す, 其際 1 個のカルボオキシル基は分解し他のカルボオキシル基は還元せら れて $-\mathrm{C} \gtrless_{\mathrm{H}}^{\mathrm{O}}$ となる。還元には特に鐵一, 亞鉛一, 銅一又は二, メル監范使用する を適當とす.

(田中)

アミノアルコール類の製法 I. G. Farbenindustrie Akt.-Ges., Frankfurt a. M. (Erfinder: Friedrich Stolz, Julius Hallensleben und Karl Boettcher, Frankfurt a. M.- Höchst). 獨逸特許 547174 號 第 2 級及第 3 級ア之ノケトン范還元して

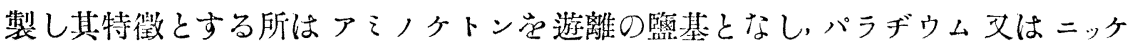
ルの如き觸媒の存在に於て承素芷以て處理するにあり.メチルアぇノプロピオ

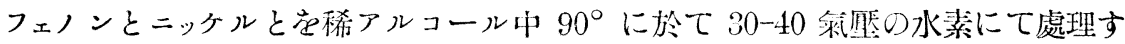
ればフェニルプロパノールメチルアンン苍得, チクロへキサンより結晶し融點

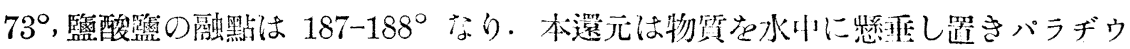

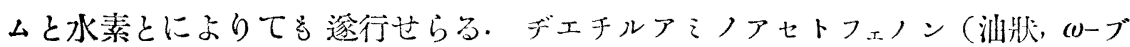

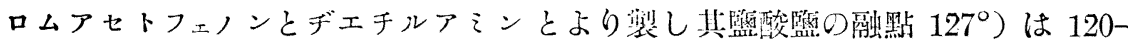
130 に於て二ッケルと 40-50 氣壓の水素とによりて相常せるアルコールとなる. 同樣にしてピペリドア七トン, pーオキシー 元し得.

(田中)

酸の分解と環狀ア三ンの製法 Knoll A.-G. und Karl Friedrich Schmidt, Ludwigshafen a. Rh. 獨逸特訢 544890 號 本法の特徵はテルペンー及カンフェル

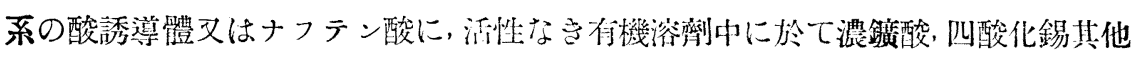
の觸媒の存在の下にアッ⿻イミド究作胢せしむるにあり.<smiles>CC(C)C1CC(C)(C(=O)O)C1</smiles><smiles>CC(C)C(C)(C)C(C)(C)C</smiles><smiles>CC1CC(C)C(C)(N)C1(C)C</smiles>

例之カンフォール酸 (I) に, 濃硫酸中にて $38^{\circ}$ に於てアツォイそド（クロロホル

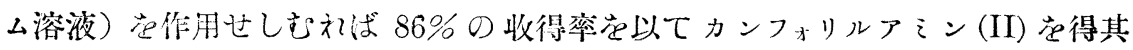
ベンツォイル誘導體の融點は $97^{\circ}$ なり．Kp·12 $118-127^{\circ}$ のナフテン酸よりは Kp. 


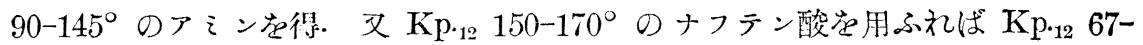
$90^{\circ}$ のア之ン写得, 又 $\mathrm{Kp} \cdot 12$ 100-230 のナフテン酸を用ふれば Kp. 85-230 の アミン混合物を得. 棓腦酸よりはヂアミン, III, 1,3-ヂアミノ-2,2,3ートリメチル チクロペンタン芷得, 水.アルコール,エーテルに甚易溶性にして融點 $124^{\circ}$, 監酸 監は融點 $313,5^{\circ}$ 又硫酸監は $312^{\circ}$ にて分解し, ピクリン酸監は $256^{\circ}$ にて分解す. ヌフェンヒョール酸 Fencholsänre よりは $\mathrm{Kp}_{{ }_{14}}$ 66-68ㅇ監基を得，（田中）

7ーアミノフェナントリドンの製法 I. G. Farbenindustrie Akt.-Ges., Frankfurt

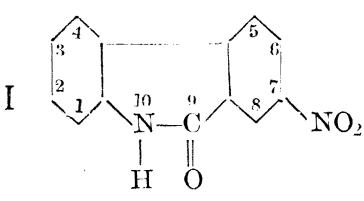
a. M. (Erfinder : Gerhard Schrader, Opladen) 獨逸特許 544524 號 本法の特徵は 7ーニトロフェ ナントリドン (I) を朁知法によりて還元するにあ り. I の還元はアンモニア溶液中にて硫化水素に より又はアルコール中にて亞鉛末と監化アンモニウム又は鐵と監酸とによりて逐

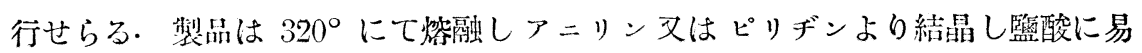
溶にしてヂアッォ化せらる.

(田中)

2ーフェニルー4ーオキシー6-アミノー1,3，5-トリアヂン類の製法Ｉ. G. Farbenindustrie Akt.-Ges., Frankfurt a. M. (Erfinder: Winfried Hentrich, Düsseldorf, und Max Hardtmann, Naunhof b. Leipzig). 獨逸特許 543112 號 本法の特徽は ヂチアンヂアミド (I) メはヂチアンヂアミヂン (II) 定安息香酸又は其䒜水物 (III) 又はクロリド(IV) と交換分解せしむるにあり，其反應は次の如し：

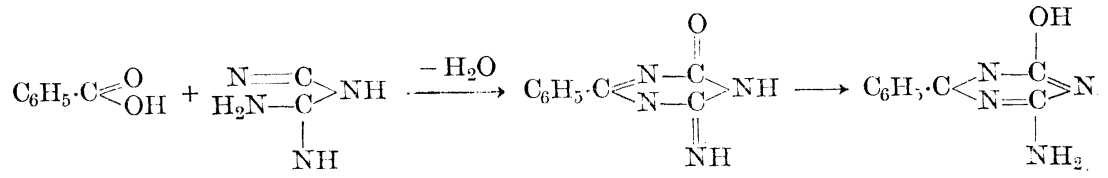
又は

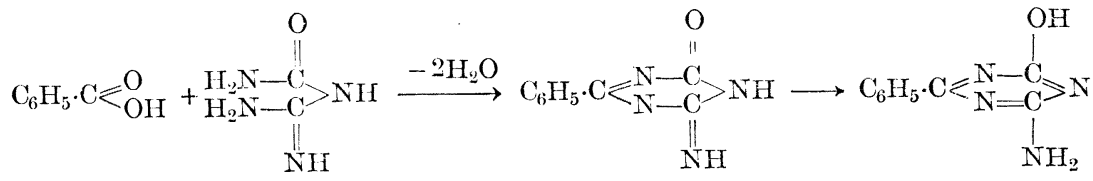

例之 I と III との混命物范 130-135 に加熱す礼ば反應生起し溫度は 220-240

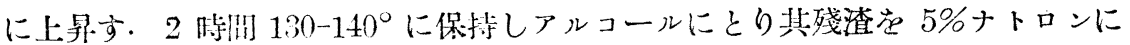

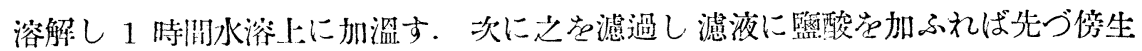


物沈澱す・而して此監酸溶液に醋酸ソーダを加ふれば 2-フェニルー4ーオキシー6ーア そノー1,3,5-トリアチン（融點 $300^{\circ}$ 以上）足得, 稀薄侍機酸に不浴にしてアルカリ， 鑛酸に易溶, 水には難溶なり，I と IV と醋酸ソーダとを 130-140に 5 時間加 熱するか又は II のヂスルファートと III と安息香酸ソーダと范130-135に 6 時間加熱する場合も上記と同一の物質を得. II と 4-×チル無水安息香酸とを 熱すれば溫度は $190^{\circ}$ に上泉し 2-(4’メチルフェニル)-4-オキシー6-アミノ - 1,3,

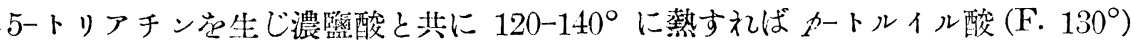
を得. 4’クロル化合物は I と4ークロルベンツォイルクロリドとより得られて融點

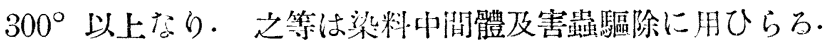

トリクロルエチレンの製法 Bozel-Maletra (Soc. Industrielle de Produits Chimiques), Frankreich. 俳國特許 715421 號 テトラクロルエタンを蒸氣狀となし $300^{\circ}$ 以下の溫度に於て活性岸上に通す。. 例之ラトラクロルエタンの蒸乘范 $260^{\circ}$ に於て 1 時間 $500 \mathrm{~g}$ の割合にて派性炭上に通市ればトリクロルエチレンを得而 して僅か $2.5 \%$ 不變テトラクロルエタン及 $5 \%$ 以下のペルクロルエチレンを念有 す,收得率は $95 \%$ な.

(田中)

リチノール酸の新誘導體の製法 Gesellschaft für Chemische Industrie in Basel, Basel. 瑞西特許 149404 號 本法の特徵はヒマシ油范フタル酸ーアースルホン酸又

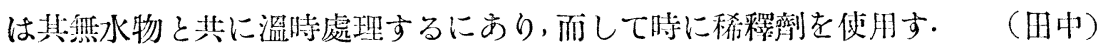

高級脂肪酸の新含硫誘導體の製法 I. G. Farbenindustrie Akt.-Ges., Frankfurt a. M. 瑞西特許 149694 號 本法の特徵はへキサクロルヒマシ油酸学硫化ソーダ と其に加壓釡中にて加熱するにあり．25.5kg のへキサクロルヒマシ油酸を $72 \mathrm{~kg}$

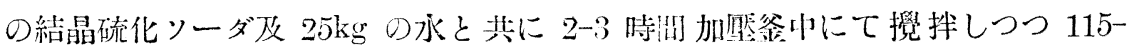
$120^{\circ}$ に加熱方.

(田中)

二鹽基性有機酸の可溶性誘導體の製法 I. G. Farbcnindustrie Akt.-Ges., Frankfurt a. M. (Frfinder: Franz Webel, Mamnheim). 獨逸特許 544288 號 例 之覮找器付加壓釜中にて 1 分の琥珀酸及 1-1.5 分のエチレンオキシドと范 80$90^{\circ}$ に於て反應せしむ. 反應成縝體中性となるや之觉水に一稀釋し必要に應じて 脫色炭と其に振湓し滤過し水及過剩のエチレンオキシドを減壓にて溜去す。立に

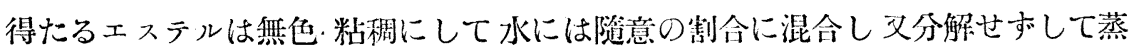
溜し得る液體にして其收得率は使用せる酸の約倍量なり．更に酒石酸,ヂグリコ 
ル酸, マレイン酸, テトラヒドロフタル酸とエチレンオキシドヌはプロピレンオキ シドメはブチレンオキシドよりもエステル家製し得. 之等エステル類はゲラチ ン, 人造物質纂の溶劑, 軟化劑として使用せらる.

(田中)

糖類の接觸還元による高級アルコールの製法 I. G. Farbenindustrie Akt.-Ges., Frankfurt a. M. (Erfinder: Johannes Müller, Fppstein b. Frankenthal, und Ulrich Hoffmann, Ludwigshafen a. Rh.), 獨逸特許 544666 號 酸化二ッケル以外 の物質にて活性化せる二ッケル又は活性ある銅又は酸化銅営觸媒として使用す。 例之 10 分の蒲葫糖に 15 分の水及 5 分のメタノール及 $2 \frac{1 \%}{2} \%$ 矹酸石灰にて活

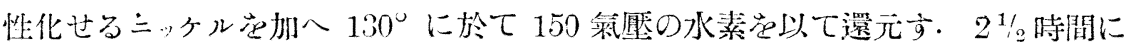
て反應は完了す．生成せるソルビットは甚だ純粹にして白色結晶性に固結す。同 稼にして果糖はマンニ,トとソルビ,トにガラクトーゼはヅルチットに又ギオキシ アセトンはグリセリンに還元せらる.

(田中)

ニトロアミノヂフェニルスルフィド類の製法 Soc. An. des Matières Colorantes et Produits Chiniques de Saint Denis und Robert Lantz, Frankreich. 俳國特許

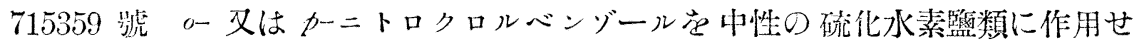
しめ次に之営间又は他のニトロクロルベンゾールと交換分解せしむ. 例之硫化り

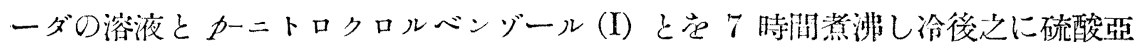

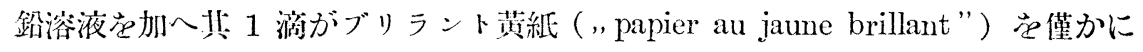

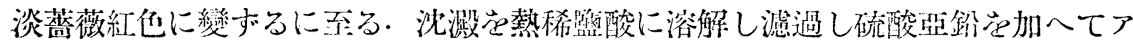

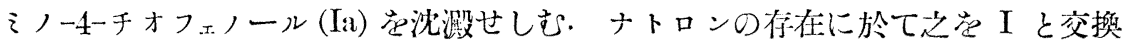

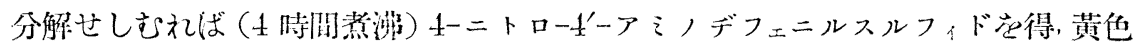
小板狀結晶にして融點 $143^{\circ}$ なり.<smiles>O=[N+]1CCC(SC2CC[Y19](O)([IH+])C2)CC1O</smiles><smiles>NC1C[Ge]CCC1SC1CCCC1[N+](=O)[O-]</smiles>

同㥞にして I と次の誘物質とを交換分解せしも：1-クロルー2-ニトロベンゾー

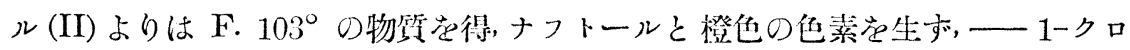
ルー2ーニトロベンゾールー4ースルホン酸よりはナトリウム礝が橙黃色結晶なる物質 を生じナフトールと赤橙色難溶の色素を生ず,一1ークロルー4ーニトロベンゾー ルー2ースルホン酸 (III) よりは黃色針狀結晶を得, ナフトールと難溶性赤橙色の色 
素な生ボー—1ークロル-2,4-ヂニトロベンゾールよりは F. 168.5 の物筫を生じ， ナフトールと赤橙色の色素觉生声, ——1ークロルー4-ニトロベンゾールー2ーカルボ ン酸よりは Zp. $215-216^{\circ}$ の物質な生じ,ナフトールとのや素は橙黄色なり, 一 1,4-ヂクロルー2-ニトロベンゾール (IV)よりは F. $133^{\circ}$ の物質を得. 之等物質は いづれも硫黃に對して

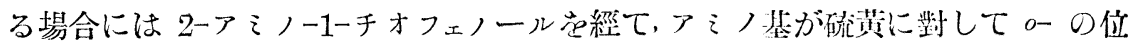
置にある物質穵得, 例之 I の作用により F. $87.4^{\circ}$ の物質空得, ナフトールとの色 素は赤橙色なり.又 II とよりは F. $85.4^{\circ}$ の物質嵒得, ナフトールとの色素は橙 黄色なり,—1ークロルー2-ニトロベンゾールー4-スルフン酸とよりは熱湯に可溶

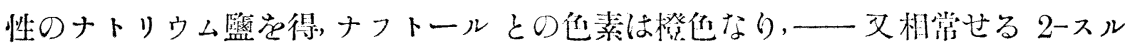
ホン酸とよりは熱湯に溶解する1種の酸な得,ナフトールとのや啋は橙黄色なり， 一1ークロルー4-ニトロベンゾールー2ーカルボン酸とよりはZ Zp. $243^{\circ}$ の物質を得, ナフトールとの色素は橙黄色なり. 又 I と III とよりはV 芷得, 灰色の小板狀 結晶にしてナトリウム籃は熱晹に可溶, ナフトールとの色素は赫なり. 又 IV よりはVI 蛋得, F. $139^{\circ} な り$.

(田中)

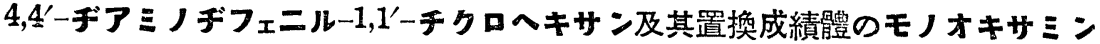

酸の製法 I. G. Farbenindustrie Akt.-Ges., Frankfurt a. M. (Erfinder : Georg Kalischer, Frankfurt a. M.. und Rinchard Fleischhauer, Frankfurt a. M.Fechenheim). 獨逸特許 546827 號 本法の特徵は $4,4^{\prime}$ ーヂアミノヂフニニルー1, $1^{\prime}$ チクロへキサンメは其置換咸續體に苳酸苍作用せしむるにあり。(英國特許 337860 號; C. 1931. II. 129. 參照).

(四中)

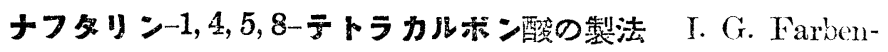
industrie Akt.-Ges., Frankfurt a. M. チェッコスロバキヤ笊竍 32312 號 右記の如き㮐造の物質荧酸性又はアルカリ性溶液に

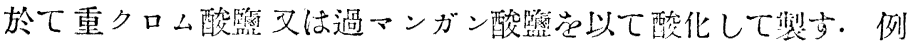

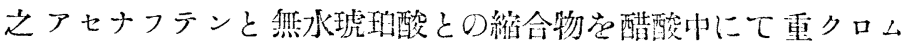
酸ソーダを以て酸化方, 溫度は $90^{\circ} な り$.

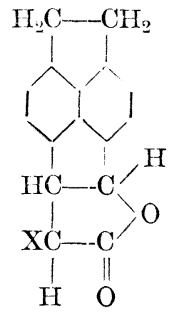

(田中)

蟻酸水溶液の濃縮法 Lanza Elektrizitätswerke und Chemische Fabriken Akt.Ges, Basel. 英國特許 369118 號 沸點高き有機慥基例之キノリン又は其混合物 $-96-$ 
の存在に於て劃溫蒸溜す. $20 \%$ 蟻酸艺 キノリン（1 モルのキノリンと 3 モル の酸）と共に劃溫蒸溜す，而して 先づ常壓にて蒸溜すれば 水の大部分溜出し其際

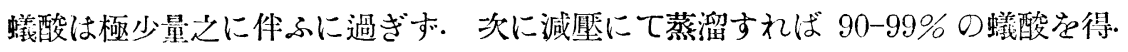

(田中)

鹽基性置換カルボン酸アミドの製法 Gesellschaft für Chemische Industrie in Basel, Basel, Schweiz. 英國特許 368590 號, 佛國特許 716500 號 反應性あるア そノアルコールエステルを $\mathrm{RCON}\left(\mathrm{R}^{1}\right) \mathrm{H}$ なる式に相當するカルボン酸アミドの

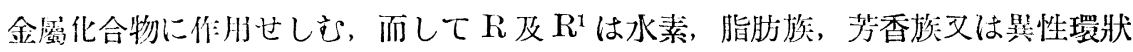

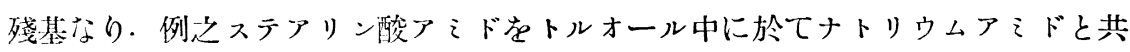
にアンモニア放尘の終止する过加熱し然る後ヂェチルアミノエチルクロリド (I)

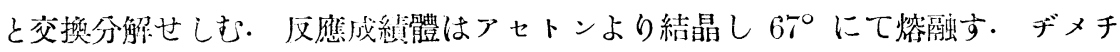

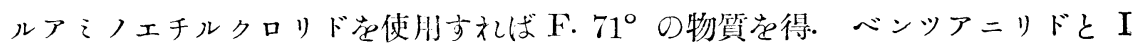
とよりはベンゾイルーN-フェニル $-\mathrm{N}-$ ヂェチルアえノエチルアミドタ得其ペルク

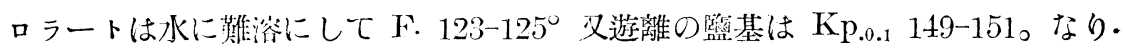

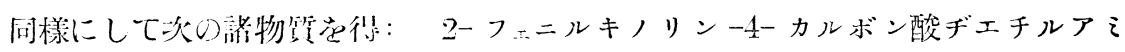
ノエチルアミド（アルコールより絬晶，F. 75） 2-nーブチルオキシキノリン-4-カ ルボン酸ヂエチルアネノエチルアネノエルルアネド（石油エーテルより結晶， F.

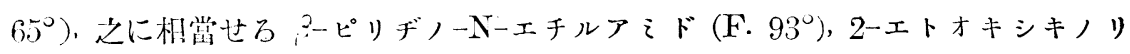

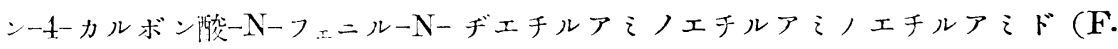

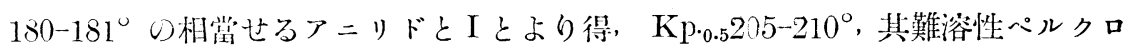

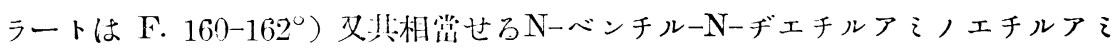

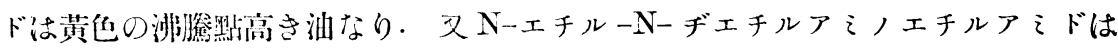

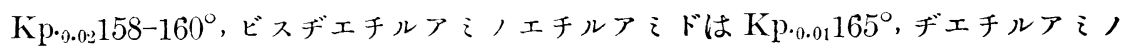

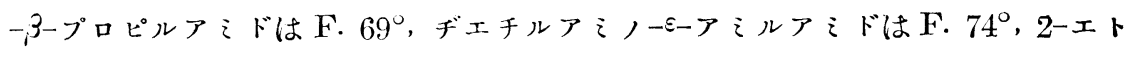
オキシー6ーブロムキノリン-4-カルボン酸ヂェチルアミノエチルアミドは F. $106^{\circ}$, ピリヂン-3-カルボン酸- $\beta$-ピペリヂノ-N-エチルアえドは其ヒドロブロブロるド の F. 182-1830,アクリヂン-9ーカルボン酸ヂエチルアミノエチルアネドは F. 105-

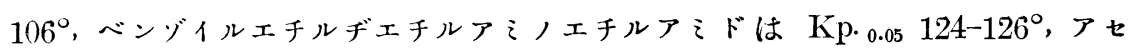

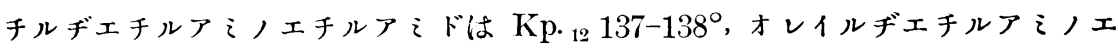
チルアネドは Kp. $0.03190^{\circ}$ なり

(田中) 
アニリン同族體の製法 National Aniline \& Chemical Co., Inc., New York, übert. von: Wesley Minnis, Buffalo, U.S.A. 米國特許 1844518 號 N-アルキ ル化アミノメチルバンゾール類のヒドロブロえドヌはヨーヂドを 230-250に加 蓺す. 例之 N-モ, ×チルーO-トルイヂンヒドロヨーヂドを究㩭拌, 還流しつつ $230^{\circ}$ に熱し次に 5 時間 $260^{\circ}$ に加熱すれば asymm. mーキシリヂン及他の成績體灾生

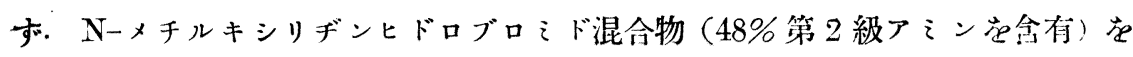
245-265に熱すればアるノトリメチルベンゾールの異性體混合物を得. N-モ， エチルーターキシリヂンヒドロヨーヂドよりはアえノヂメチルエチルベンデールを 生ず.

(田中)

無水フタル酸ー $\beta$ ースルホン酸の製法 Gesellschaft für Chemische Industrie in Basel, Basel. 瑞西特竍 150612 等 63.5 分の!無分フタル酸范 103 分の無水硫酸 と共に長時間加壓釡中にて $135-140^{\circ}$ に加熱す. 水を注入し監析してフタル酸一

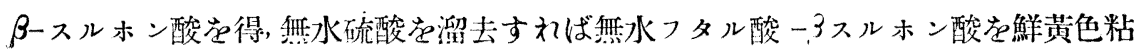
皏の物質として得.

(田中)

桂皮酸の製法 Radio Patents Corp., übert. von: George Bacharach, New York, U. S. A. 米國特許 1853030號 少量のピリヂンの存在に於て Perkin 氏反 應を行ひて製す，例之新に雚溜したる心゙ンズアルデヒド $20 \mathrm{~g}$ を新に蒸溜したる 無水醋酸 $30 \mathrm{~g}$ 及無水の醋酸ソーダ $10 \mathrm{~g}$ と混じ之に 8 滴のピリヂンを加へ 8 時 間還流冷却下に $165^{\circ}$ に加熱すれれば桂皮酸を得其收得率 $85 \%$ なり.（田中）

グリオキサリン同族體の製法 Boots Pure Drug Co. Ltd., Alexander Peter Tawse Easson und Frank Lee Pyman, Nattingham, England. 英國特許 365281 號 二硫化炭素の存在に於てアミノアセタールに荷性ソーダ溶液を作用せしめ然

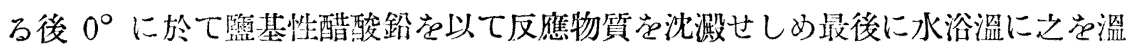
めアセタリルチオカルブイそド(I), Kp. $40130^{\circ}$ を得. 之を 1 モルのアニリンと 共に 1 時間 $100^{\circ}$ に熱すればフェニルアセタリルチオ尿素, F. 96-97 足得. 8アミノキノリンをＩに作用（1 時間, $100^{2}$ に加熱）せしむれば先づアセタリキ ノリチオ尿素觉生じ之を 1 時間稀硫酸と共に溫むれば 1-(キノリルー8)-2-チオ

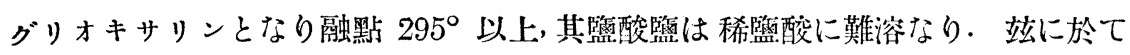
之に熱硝酸（2.5-n）在作用せしむれば 1-(キノリルー8)ーグリオキサリン（F.124$\left.125^{\circ}\right)$ を生じ其鹽酸盬は F. 244-245 なり. 又 I と 2-アぇノキノリンとより 
は 2-キノリルアセタリルチオ尿素な生じ (F. 138-139), 之は稀硫酸によりて 1キノリルー2)-2-チオグリオキサン (F. 260-261º) となり之觉硝酸にて酸化すれば 1-(キノリル-2)-グリオキサン(F. 120-1210) となり其モノヒドロクロリドは F. 217-218 なり． 6-メトオキシ-8-アえノキノリンよりは同樣にして F. $294^{\circ}$ チ オグリオキサリン唀導體を經て 1-(6-メトオキシキノリルー8)-グリオキサリン(F.

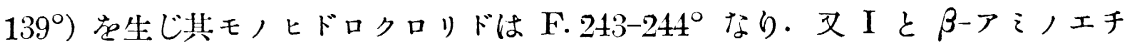

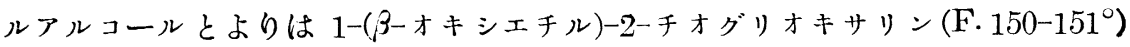

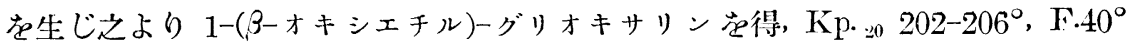
なり．アえノ醋酸エチルェステルをＩと交換分解せしめ生成せる中間成績體を

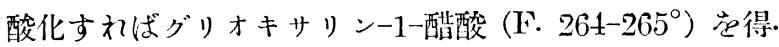

\section{il: 誤 表 (若者原稿訂正)}

第 53 能 第 3 號

\begin{tabular}{|c|c|c|c|}
\hline 頁 & 行 & 漷 & 正 \\
\hline 275 & 上より 3 行目 & 蝲蛅の蝴蛅の & 蛉站の \\
\hline " & 上より 10 行目 & 溶被及試驗龙 & 溶液及試驗长 \\
\hline 276 & 上より 4 行目 & 昨年 6 月より令年 6 月 & 昭和 6 年 6 月 -7 年 6 月 \\
\hline '" & 下より 2行目 & （水性一 1.3 ) & （水性比重1.3） \\
\hline 278 & 上より 4 行目 & 第2報 & 第 2 表 \\
\hline 281 & 上より 5行目 & 活動のもの & 活動期のもの \\
\hline " & 上より 11 行目 & ルレゴン産蝴蛄 & オレゴン産蝲蛅 \\
\hline " & 參考文獻 & Drumond \&. Rosenhein. & $\begin{array}{l}\text { 1. O. Rosenheim and J. C. Dru- } \\
\text { mmond: Biochem. J. 19, } 753 \\
(1925) \text {; W. H. Willimott, T. } \\
\text { Moor, and F. Wokes: Biochem. } \\
\text { J. 20, } 1292(1926) \text {; Lancet } 21 . \\
\text { Jaarnr } 1928,148 \text {. }\end{array}$ \\
\hline
\end{tabular}




\section{衞生技術員協議會決定事項}

衛生技術員協議會に於て協議決定したる事项左記の如し

\section{粉乳(乾燥 乳)檢查法}

\section{緒言}

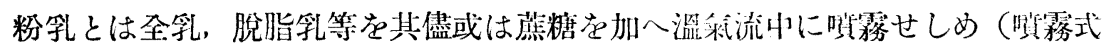
粉乳) 又は熱したる圓筒面上に蒸發せしめて(国箈式粉乳)製したる粉末にして原 料の種類により全粉乳, 脫脂粉乳等范區別し又器糖范加へたるものを加糖粉乳と 稱す

試驗すべき事項次の如し
1. 容器の外觀的检査
2. 外觀及乘味
3. 溶解度
4. 酸 度
5. 顯微鏡的試駘
6. 水 分
7. 脂 肪
8. 含空素物(蛋白質)
9. 糖分 (乳糖, 蔍糖)
10. 鐄物筫 (灰分)
11.アルカリ度及燐酸
12. 變 敗
13. エンチーム
14. 晎種脂肪
15. 細菌數
16. 重金屬
17. 防腐劑
18. 澱 粉
19. 著色料

$$
\text { 試 驗方法 }
$$

可檢品の各部より適宜少量宛を硝子嚗に探取し密栓して混和し試驗に潩すべし

1. 容器の外觀的檢查

可檢品は開鑵に先立ち鑵の破損其他簧常なきや否やを檢すべし

2. 外觀及氣味

先づ外觀及氣味を檢し次に約 $5 \mathrm{~g}$ を取り之に 10 倍量の溫湯を注ぎ㩭排し其香 氣及風味を檢すべし

4. 酸 度

試料 $10 \mathrm{~g}$ を水 $100 \mathrm{cc}$ に溶解し之にフエノールフタレインのアルコール溶液 $(2$ 
\%) 2ce を注加し $\mathrm{N} / 4$ アルカリ液を滴加して全液微に紅色を呈するに至るべし立 に消費せるアルカリ液の $\mathrm{cc}$ 數觉以て酸度とす

6. 水 分

精製珪砂又は浮石末約 $15 \mathrm{~g}$ を扁平称量曇に取り小硝子棒を附し $105^{\circ}$ に於て乾 燥し科量したる後之に試料 $2 \mathrm{~g}$ 灾容れ善く混和し $100^{\prime}$ に於て乾燥し最初一時間 の後爾後 30 分每に科量し恒量を得るに至り乾燥減失量より水分の\%量を算定す へし但乾燥の都度硝子棒を以て內容を㩭捧する要す

7. 脂 肪

（1）重量法 萢料 $2 \mathrm{~g}$ をべ, ルルに取り水 20-30cc を加八加溫して溶解し 冷後水を追加して約 $400 \mathrm{cc}$ に稀釋し以下煉乳檢査法中脂肪の定量法（イ）に從ひ 操作すべし

（ロ）振漫法 試料 $1 \mathrm{~g}$ を圖の如きリヨーリ, ヒ Röhrig 管又はリーテル Rieter 管に取り水 $10 \mathrm{ce}$ を加八熱湯中に挏入し動搖して均等の液を得るに至りアン

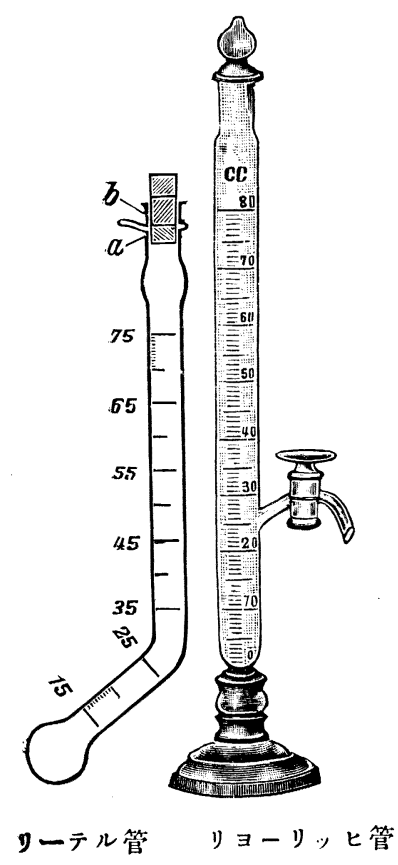

9. 榶 分 モニア水 $1 \mathrm{cc}$ 学混和し冷却したる後 $95 \%$ のアルコール10ccを加へ振壍し以下煉乳检 查法中脂肪の定量法(口)に從ひ操作すべし 脫脂粉乳に在りては試料 $5 \mathrm{~g}$ を內容 200 $250 \mathrm{cc}$ の共栓劃度硝子圓筒に取り水 $30 \mathrm{cc}$ 及 アンモニア水 $3 \mathrm{cc}$ を加へて溶解し之に 95 \%のアルコール $30 \mathrm{cc}$ を加へて振壍し次に エーテル及石油エーテル各 $75 \mathrm{cc}$ を順次に 加へ每问强く振蕰し靜置したる後分離せる エーテル性液より $100 \mathrm{cc}$ を分取し其蒸發殘 渣を科定し其量より脂肪の\%量を算定すへ ᄂ

\section{8. 含絰素物 (蛋白質)}

試料 1-2g を取りキールダール法に從ひ て窒素を定量し之に 6.37 を乘し其量より 含窒素物の\%量を算定すへし 
(甲) 乳 糖

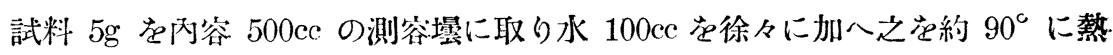
して均等の液となし冷後水約 300cc 旮追加し脂肪定量法に於けるが如く之に硫酸

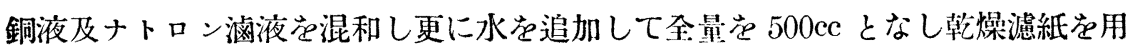

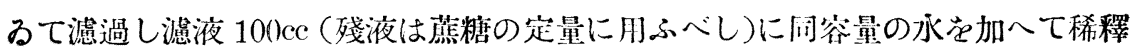
し其 $100 \mathrm{cc}$ (試料 $0.5 \mathrm{~g}$ に相當す) 范沸騰つニーリング溶液 50ce 中に注ぎ 6 分間 煮沸し茲に析出せる亞酸化銅の沈泝范硝子滤過管又は石綿滤過管范仃るて吸引滤

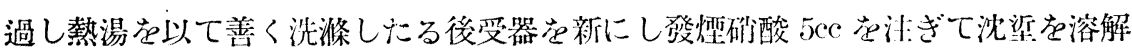

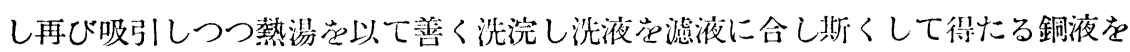

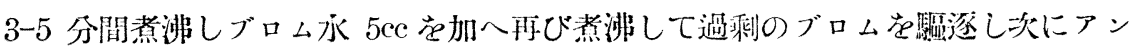

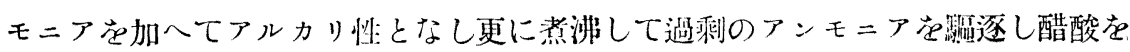

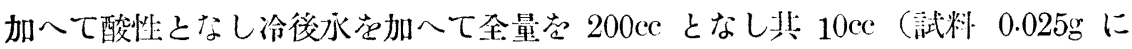
相當す)を取り己にョードカリ $2 \mathrm{~g}$ 及水 $50 \mathrm{cc}$ 芷混加し立にに析州せるョードを澱

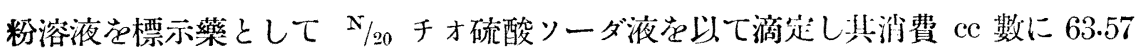

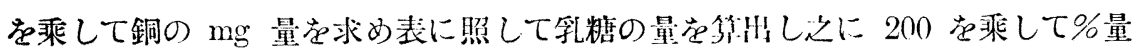
とすべし

\section{(乙) 蔴 糖}

試料 $6 \mathrm{~g}$ を取り水 $50 \mathrm{cc}$ を加へ約 $90^{\circ}$ に熱して均等の液となし其 $30-45 \mathrm{cc}$ を 取り之に飽和醋酸鎦溶液 2 容量及アンモ二ア水 1 谷量の制合觉以て新に製した

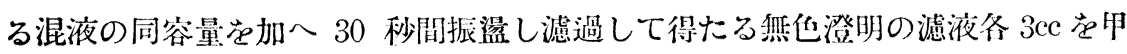
乙 2 筒の試驗管に取り甲管にヂフェニールアミン試藥(アルコール性 $10 \%$ ア゙フェ

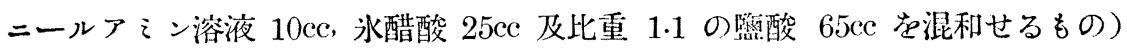
$3 \mathrm{cc}$ を加へ乙管にフェーリング浚液 $3 \mathrm{cc}$ 学加へ雨管觉沸湯中に雨入し 10 分間加

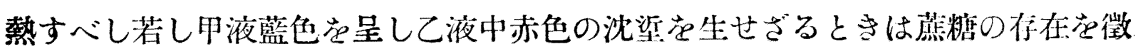
$す$

前記の試驗に於て鷹糖の存在を認めたるときは䚿の方法により之を定量すべし 前上乳糖の定量に於て保存せる殘液より $100 \mathrm{cc}$ 茛硝子嚗に取り定規監酸 $2 \mathrm{cc}$ を

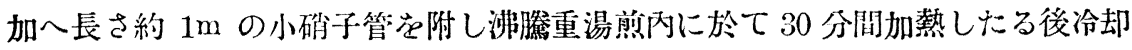

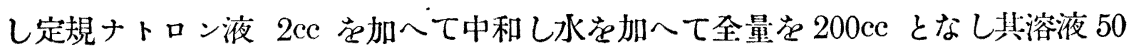
cc (試料 $0.25 \mathrm{~g}$ に相當す) を沸䐋フェーリング溶液 $50 \mathrm{cc}$ 中に注ぎ 2 分間煮沸し 
立に析出せる亞酸化銅の沈垽を乳糖の定量に於ける如く處理して銅量を求め表に 照して轉化糖の量を䇢出し次式により鷹糖の\%量を算定すべし

$$
\mathrm{x}=0.95\left(400 \mathrm{a}-\frac{\mathrm{b}}{1.4}\right)
$$

式中 a は轉化糖の $\mathrm{g}$ 量, $\mathrm{b}$ は乳糖の\%量とす

（丙）糖分の概量檢定

正確を姴せさる場合に於ては次の方法を應用すること茛得べし

（イ）無糖粉乳に在りては澱粉等の晎物を混在せす其品質純良なることを涊め たるときは乾燥物質の總量より脂肪, 含辜素物及灰分の總量を減じ其差を以て乳 糖の概量と在做し得べし

（口）加糖粉乳に在りては原料牛乳中の乳糖含量を脂肪, 含空素物及灰分の總 量の60\%に相當すと看做し混加せる蔴糖の量を概算し得べし

10. 鐄物質 (灰分)

試料 $2 \mathrm{~g}$ 芷白金血に取り灰化し科量すべし

16. 重金屬

試料 $10 \mathrm{~g}$ 足取りキールダール法により有機物を分解したる後常法に從ひ之を检 すべし 


\section{空氣檢查法中一部改正}

\section{1. 炭酸の定量}

\section{本定量には次の裝置及試藥を要す}

\section{装置}

1. 捕籍㬡 (第 1 圖 A)

內容約 $1 l$ の硬質硝子增

口. 小硝子嚗 (第 1 圖 B)

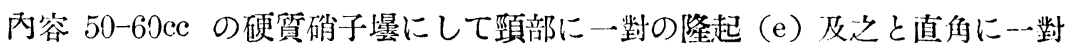
の小孔 (f) 学有す

八. 連通确子栓 (第 1 圖 C)

一端及側壁に於て $\mathrm{g}$ 及 $\mathrm{h}$ に開口する 2 條の細管站に 1 對の把手 $(\mathrm{j})$ を有 する硝子栓にして前記捕氣壖と小硝子嚗とを連結するの用に供す

二. 滴定壆 (第 1 圖 D)

內容 100-120ec の共栓硬質硝子嚗

捕氣㬡, 小硝子嚗及連通硝子栓は磨合せにより第 2 圖の如く氣密に連結するも

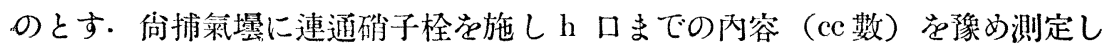
置くべし

第 1 圖
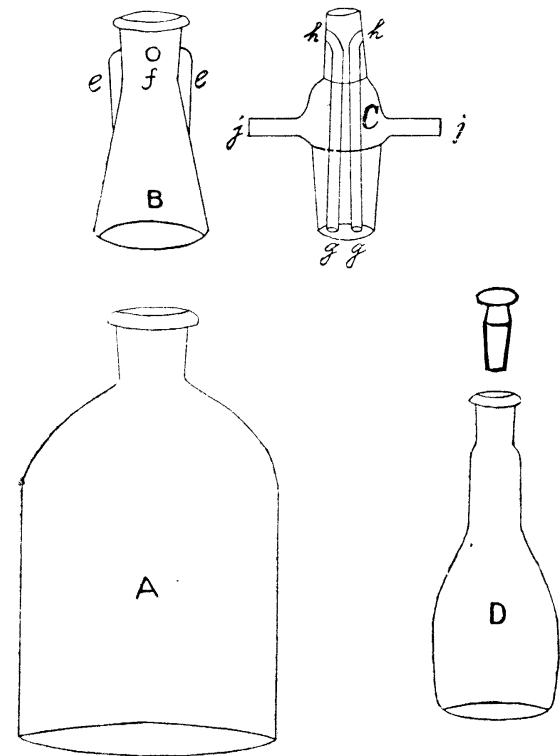

第 2 圆

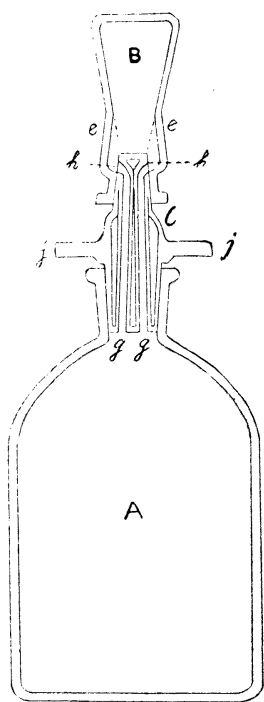


試藥”

1. バリツト液

精製水酸化バリウム $1.4 \mathrm{~g}$ 及臨化バリウム $0,08 \mathrm{~g}$ 学水に溶解し全量を $1 l$ と なすべし

本液は常に炭酸を除去せる空氣中に咛藏し且量取に際し成るべく焱酸に接觸 することなき㥞注意すべし

2. 苳酸 液

純修酸 $\left(\begin{array}{l}\mathrm{COOH} \\ \mathrm{COOH}\end{array}+2 \mathrm{H}_{2} \mathrm{O}\right) 0.5632 \mathrm{~g}$ を水に溶解し全量を 1 . となすべし

本液 $1 \mathrm{ce}$ は標淮状態に於ける炭酸 $\left(\mathrm{CO}_{2}\right) 0.1 \mathrm{ce} に$ に相當す.

定量法

小㗂子嚗を取り豫め炭酸を除去せる空氣を迭入して嚗內の空氣を置撸せる後バ リット液 50ec を注入し值に連通确子栓芭以て閉塞し h 口と $\mathrm{f}$ 口とを合致せ

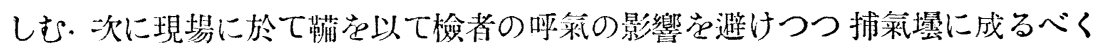

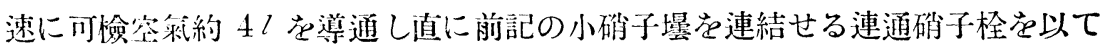

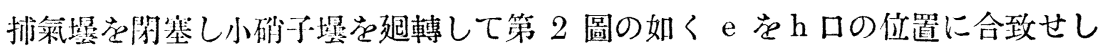
めバリット液觉して捕氣嚗中に流入せしめ同時に現場の氣溫及氣捱な测定すべ

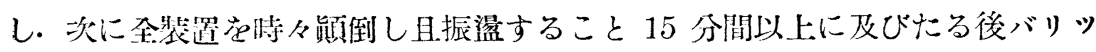

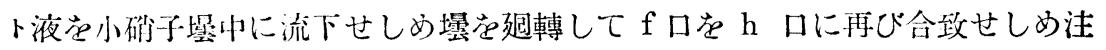
意して捕武嚗を除き3 時䦌以上放置し生成せる炭酸バリウムの全く沈着した

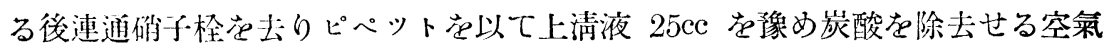

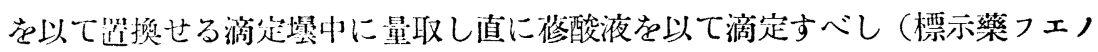
ールフタレイン浴液)

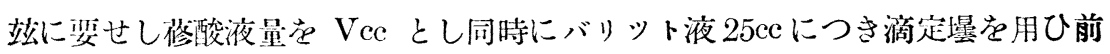
同樣に操作して滴定し之に要せし葆酸液量を $\mathrm{V}_{0} \mathrm{cc}$ とすれば可檢空氣中の炭酸 含量を算定吉る式次の如し.

$$
\text { 炭酸含量 }(\mathrm{cc} / \mathrm{L})=\frac{200\left(\mathrm{~V}_{0}-\mathrm{V}\right)}{\mathrm{N} \cdot \mathrm{K}}
$$

式中 $\mathrm{N}$ は捕氣嚗に連通硝子栓を施したるときの h 口までの ce 數にして $\mathrm{K}$ は捕集時の莱溫氣壓より標淮狀態に換算する係數なり(別表參照)

標準状態換算係数表 (一)

\begin{tabular}{|c|c|c|c|c|c|c|c|c|c|c|c|}
\hline 氣 燞 & 730 & 731 & 732 & 733 & 734 & 735 & 736 & 737 & 738 & 739 & 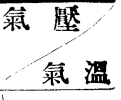 \\
\hline 0 & 0.960 & 0.962 & 0.963 & 0.964 & 0.966 & 0.967 & 0.968 & 0.970 & 0.971 & 0.972 & 0 \\
\hline 1 & 957 & 9.58 & 960 & 961 & 962 & 964 & 965 & 966 & 967 & 969 & 1 \\
\hline 2 & 954 & 955 & 956 & 957 & 959 & 960 & 961 & 963 & 964 & 965 & 2 \\
\hline 3 & 950 & 951 & 953 & $9 \check{5}$ & 955 & 957 & 958 & 959 & 960 & 962 & 3 \\
\hline
\end{tabular}




\begin{tabular}{|c|c|c|c|c|c|c|c|c|c|c|c|}
\hline 4 & 947 & 948 & 949 & 951 & 952 & 953 & 955 & 956 & $9 \tilde{5} 7$ & 958 & 4 \\
\hline j & 943 & 945 & 946 & 947 & 948 & 950 & $9 \lesssim 1$ & 952 & 9.54 & 955 & 5 \\
\hline 6 & 940 & 941 & 942 & 944 & 945 & 346 & 948 & 949 & 950 & 951 & 6 \\
\hline 7 & 937 & 938 & 939 & 940 & 942 & 943 & 944 & 946 & 947 & 948 & 7 \\
\hline 8 & 933 & 934 & 936 & 937 & 938 & 940 & 941 & 942 & 943 & 945 & 8 \\
\hline 9 & 930 & 931 & 932 & 934 & $93 \check{5}$ & 936 & 938 & 939 & 940 & 941 & 9 \\
\hline 10 & 927 & 928 & 929 & 930 & 932 & 933 & $9: 34$ & 935 & 937 & 938 & 10 \\
\hline 11 & 923 & 925 & 926 & 927 & 928 & 930 & 981 & 982 & 938 & 935 & 11 \\
\hline 12 & 920 & 921 & .923 & 924 & 925 & 926 & $9): 8$ & 929 & 930 & 931 & 12 \\
\hline 13 & 917 & 918 & 919 & 921 & 922 & 923 & 924 & 926 & 927 & 928 & 13 \\
\hline 14 & 914 & 915 & 916 & 917 & 919 & 920 & 921 & 922 & 924 & 925 & 14 \\
\hline 15 & 910 & 912 & 913 & 914 & 915 & 917 & 918 & 919 & $9: 0$ & 922 & 15 \\
\hline 16 & 907 & 909 & 910 & 911 & 912 & 914 & 915 & 916 & 917 & 919 & 16 \\
\hline 17 & 904 & 90 气 & 907 & 908 & 909 & 910 & 912 & 913 & 914 & 915 & 17 \\
\hline 18 & 901 & 902 & 904 & 905 & 906 & 907 & 909 & 910 & 911 & 912 & 18 \\
\hline 19 & 898 & 899 & 900 & 902 & 903 & 904 & 906 & 907 & 908 & 909 & 19 \\
\hline 20 & 895 & 896 & 897 & 899 & 900 & 901 & 902 & 903 & 905 & 906 & 20 \\
\hline 21 & 892 & 893 & 894 & 896 & 897 & 898 & 899 & $90)$ & 902 & 903 & 21 \\
\hline 22 & 889 & 890 & 891 & 893 & 894 & $89 \check{~}$ & 896 & 897 & 899 & 900 & 22 \\
\hline 23 & 886 & 887 & 888 & 889 & 891 & 892 & 893 & 894 & 896 & 897 & 23 \\
\hline 24 & 883 & 884 & $88 \tilde{3}$ & 886 & 888 & 889 & 890 & 891 & 893 & 894 & 24 \\
\hline 25 & 880 & 881 & 882 & 884 & $88 \check{5}$ & 886 & 887 & 888 & 890 & 891 & 25 \\
\hline 26 & 877 & 878 & 879 & 881 & 882 & 883 & 884 & 885 & 887 & 888 & 26 \\
\hline 27 & 874 & 875 & 876 & 878 & 879 & 880 & 881 & 882 & 884 & 885 & 27 \\
\hline 28 & 871 & 872 & 873 & 875 & 876 & 877 & 878 & 879 & 881 & 882 & 28 \\
\hline 29 & $86 ̋ 8$ & 869 & 871 & 872 & 873 & 874 & 875 & 877 & 878 & 879 & 29 \\
\hline 30 & 865 & 867 & 868 & 869 & $\$ 70$ & 871 & 873 & 874 & 875 & 876 & 30 \\
\hline 31 & 863 & 864 & 865 & 866 & 867 & $\$ 68$ & 870 & 871 & 872 & 873 & 31 \\
\hline 32 & 860 & 861 & 862 & 863 & 864 & 866 & 867 & 868 & 869 & 870 & 32 \\
\hline 33 & 857 & 858 & 8599 & 860 & 862 & 863 & 864 & 805 & 866 & 868 & 33 \\
\hline 34 & 854 & 855 & 856 & 858 & 859 & 860 & 861 & 862 & 863 & 86.5 & 34 \\
\hline 35 & $8 \check{1} 1$ & 852 & 854 & 855 & 856 & 857 & 8.58 & 8.59 & 861 & 862 & 35 \\
\hline 36 & 849 & 850 & 851 & 852 & 853 & 854 & $\sin 6$ & 857 & 858 & 859 & 36 \\
\hline 37 & 846 & 847 & 848 & 849 & 850 & 852 & 853 & 854 & 855 & 856 & 37 \\
\hline 38 & 843 & 844 & 845 & 847 & 848 & 849 & 850 & 851 & 852 & 854 & 38 \\
\hline 39 & 840 & 842 & 843 & 844 & 845 & 846 & 847 & 840 & $8 \check{0} 0$ & 851 & 39 \\
\hline 40 & 838 & S39 & 840 & 841 & 842 & 843 & $84 \check{\jmath}$ & 846 & 847 & 848 & 40 \\
\hline
\end{tabular}


標準狀態換算係數表 (二)

\begin{tabular}{|c|c|c|c|c|c|c|c|c|c|c|c|}
\hline 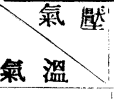 & 740 & 741 & 742 & 743 & 744 & 745 & 746 & 747 & 748 & 749 & 氣 \\
\hline 0 & 0.974 & 0.975 & 0.976 & 0.978 & 0.979 & 0.980 & 0.982 & 0.983 & 0.984 & 0.985 & 0 \\
\hline 1 & 970 & 971 & 973 & 974 & 975 & 977 & 978 & 979 & 981 & 982 & 1 \\
\hline 2 & 967 & 968 & 969 & 970 & 972 & 973 & 974 & 976 & 977 & 978 & 2 \\
\hline 3 & 963 & 964 & 966 & 967 & 968 & 970 & 971 & 972 & 973 & 975 & 3 \\
\hline 4 & 960 & 961 & 962 & 963 & 965 & 966 & 967 & 969 & 970 & 971 & 4 \\
\hline 5 & 956 & 957 & 959 & 960 & 961 & 963 & 964 & 965 & 966 & 968 & 5 \\
\hline 6 & $95 \%$ & 954 & $9 \overline{3} \overline{5}$ & 957 & 958 & 959 & 960 & 962 & 963 & 964 & 6 \\
\hline 7 & 949 & 951 & $95:$ & 953 & $95 \overline{5}$ & 956 & 957 & 958 & 960 & 961 & 7 \\
\hline 8 & 946 & $94 \vec{\imath}$ & 948 & 950 & 951 & 952 & 954 & 955 & 956 & 957 & 8 \\
\hline 9 & 943 & 944 & (9) 45 & 946 & 948 & 949 & $9 \check{0} 0$ & 952 & 953 & 954 & 9 \\
\hline 10 & 939 & 940 & 942 & 943 & 944 & 946 & 947 & 948 & 949 & 951 & 10 \\
\hline 11 & 936 & 937 & 938 & 940 & 941 & 942 & 944 & 945 & 946 & 947 & 11 \\
\hline 12 & 933 & 934 & 935 & 936 & 938 & 939 & 940 & 941 & 943 & 944 & 12 \\
\hline 13 & 929 & $9: 31$ & 932 & 933 & 934 & 93 & 937 & 938 & 939 & 941 & 13 \\
\hline 14 & 926 & 927 & 929 & 930 & 981 & 932 & 934 & $93 \check{0}$ & 936 & 937 & 14 \\
\hline 15 & 923 & 924 & 925 & 927 & 928 & 929 & 930 & 922 & 933 & 934 & 15 \\
\hline 16 & 920 & 921 & 922 & 923 & 925 & 926 & 927 & 928 & 930 & 931 & 16 \\
\hline 17 & 917 & 918 & 919 & $9 \succeq 0$ & 922 & 923 & 924 & 925 & 926 & 928 & 17 \\
\hline 18 & 913 & 915 & 916 & 917 & 918 & 920 & 921 & 922 & 923 & 925 & 18 \\
\hline 19 & 910 & 912 & 913 & 914 & 915 & 916 & 918 & 919 & $9: 0$ & 921 & 19 \\
\hline 20 & 907 & 908 & 910 & 911 & 912 & 913 & 915 & 918 & 917 & 918 & 20 \\
\hline 21 & 904 & $90 亏$ & 907 & 908 & 909 & 910 & 911 & 913 & 914 & 915 & 21 \\
\hline 22 & 901 & 902 & 903 & 905 & 906 & 907 & 908 & 910 & 911 & 912 & 22 \\
\hline 23 & 898 & S99 & 900 & 902 & 903 & 904 & 905 & 906 & 908 & 909 & 23 \\
\hline 24 & 395 & 896 & 897 & 899 & 900 & 901 & 902 & 903 & 905 & 906 & 24 \\
\hline 25 & 892 & 893 & 894 & 896 & 897 & 898 & 899 & 900 & 902 & 903 & 25 \\
\hline 26 & 889 & 890 & 891 & 893 & 894 & 895 & 896 & 897 & 899 & 900 & 26 \\
\hline 27 & 886 & 887 & 888 & 890 & 891 & 892 & 893 & 894 & 896 & 897 & 27 \\
\hline 28 & 883 & 884 & 885 & 887 & 888 & 889 & 890 & 891 & 893 & 894 & 23 \\
\hline 29 & 880 & 881 & 883 & 884 & 885 & 886 & 887 & 888 & 890 & 891 & 29 \\
\hline 30 & 877 & 878 & 880 & 881 & 882 & 883 & 884 & 886 & 887 & 888 & 30 \\
\hline 31 & 874 & 876 & 877 & 878 & 879 & 880 & 881 & 883 & 884 & 885 & 31 \\
\hline 32 & 871 & 873 & 874 & 875 & 876 & 877 & 879 & 880 & 881 & 882 & 32 \\
\hline 33 & 869 & 870 & 871 & $87 \%$ & 873 & 875 & 876 & 877 & 878 & 879 & 33 \\
\hline 34 & 866 & 867 & 868 & 869 & 870 & 872 & 873 & 874 & $87 \bar{\jmath}$ & 876 & 34 \\
\hline
\end{tabular}


錄

\begin{tabular}{l|l|l|l|l|l|l|l|l|l|l|l}
35 & 863 & 864 & 865 & 866 & 868 & 869 & 870 & 871 & 872 & 873 & 35 \\
\hline 36 & 860 & 861 & 863 & 864 & 865 & 866 & 867 & 868 & 870 & 871 & 36 \\
37 & 857 & 859 & 860 & 861 & 862 & 863 & 864 & 866 & 867 & 868 & 37 \\
38 & 855 & 856 & 857 & 858 & 859 & 860 & 862 & 863 & 864 & 865 & 38 \\
39 & 852 & 853 & 854 & 855 & 856 & 858 & 859 & 860 & 861 & 862 & 39 \\
40 & 849 & 850 & 852 & 853 & 854 & 855 & 856 & 857 & 858 & 860 & 40
\end{tabular}

標準狀態換算係数表（三）

\begin{tabular}{|c|c|c|c|c|c|c|c|c|c|c|c|}
\hline 氣 黶 & 750 & 751 & 752 & 753 & 754 & 755 & 756 & 757 & 758 & 759 & 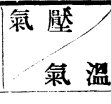 \\
\hline 0 & 0.987 & 0.988 & 0.989 & 0.991 & 0.992 & 0.993 & 0.994 & 0.996 & 0.997 & 0.999 & 0 \\
\hline 1 & 983 & 985 & 986 & 987 & 988 & 990 & 991 & 992 & $! 94$ & 995 & 1 \\
\hline 2 & 980 & 981 & 982 & 934 & 985 & 986 & 987 & 989 & 990 & 991. & 2 \\
\hline 3 & 976 & 977 & 979 & 980 & 981 & 983 & 984 & $98 \overline{5}$ & 986 & 988 & 3 \\
\hline 4 & 973 & 974 & 975 & 976 & 978 & 979 & 980 & 982 & 983 & 984 & 4 \\
\hline 5 & 969 & 970 & 972 & 973 & 974 & 976 & 877 & 978 & 979 & 981 & $\tilde{J}$ \\
\hline 6 & 966 & 967 & 968 & 969 & 971 & 972 & 973 & 975 & 976 & 977 & 6 \\
\hline 7 & 962 & 964 & 965 & 966 & 967 & 968 & 970 & 971 & 973 & 974 & 7 \\
\hline 8 & 959 & 960 & 961 & 963 & 964 & 965 & 966 & 968 & 969 & 970 & 8 \\
\hline 9 & 955 & 957 & 958 & 959 & 960 & 962 & 963 & 964 & 966 & 967 & 9 \\
\hline 10 & 952 & 953 & 954 & 956 & 957 & 958 & 960 & 961 & 962 & 963 & 10 \\
\hline 11 & 949 & 9.50 & 951 & 952 & 954 & 955 & 956 & 957 & 959 & 960 & 11 \\
\hline 12 & 94.5 & 946 & 948 & 949 & 950 & 952 & 9.3 & 9.54 & 9.55 & 957 & 12 \\
\hline 13 & 942 & 943 & $94 \cdot 4$ & 946 & 947 & 948 & 949 & 9.11 & 952 & 953 & 13 \\
\hline 14 & 939 & 940 & 941 & 942 & 944 & 945 & 946 & 947 & 949 & 950 & 14 \\
\hline 15 & $93 \check{0}$ & 937 & 938 & 939 & 940 & 942 & 943 & 944 & $94 \check{\jmath}$ & 947 & 15 \\
\hline 16 & 932 & 933 & 935 & 936 & 937 & 938 & 940 & 941 & 942 & 943 & 16 \\
\hline 17 & 929 & 930 & 931 & 933 & 934 & 935 & 936 & 938 & 939 & 940 & 17 \\
\hline 18 & 926 & 927 & 928 & 930 & 931 & 932 & 933 & 934 & 936 & 937 & 18 \\
\hline 19 & 923 & 924 & 925 & 926 & 927 & 929 & 930 & 931 & 932 & 934 & 19 \\
\hline 20 & $9 \mathrm{I} 9$ & 921 & 922 & 923 & 924 & 926 & 927 & 928 & 929 & 930 & 20 \\
\hline 21 & 916 & 918 & 919 & 920 & 921 & 922 & 924 & 925 & 926 & 927 & 21 \\
\hline 22 & 913 & 914 & 916 & 917 & 918 & 919 & 921 & 922 & 923 & 924 & 22 \\
\hline 23 & 910 & 911 & 913 & 914 & 915 & 916 & 917 & 919 & 920 & 921 & 23 \\
\hline 24 & 907 & 908 & 909 & 911 & 912 & 913 & 914 & 916 & 917 & 918 & 24 \\
\hline 25 & 904 & 905 & 906 & 908 & 909 & 910 & 911 & 912 & 914 & 915 & 25 \\
\hline 26 & 901 & 902 & 903 & 905 & 906 & 907 & 908 & 909 & 911 & 912 & 26 \\
\hline 27 & 898 & 899 & 900 & 902 & 903 & 904 & 905 & 906 & 903 & 909 & 27 \\
\hline
\end{tabular}




\begin{tabular}{l|l|l|l|l|l|l|l|l|l|l|l}
\hline 28 & 895 & 896 & 897 & 899 & 900 & 901 & 902 & 903 & 905 & 906 & 28 \\
29 & 892 & 893 & 894 & 896 & 897 & 898 & 899 & 900 & 902 & 903 & 29 \\
30 & 889 & 890 & 891 & 893 & 894 & 895 & 896 & 897 & 898 & 900 & 30 \\
\hline 31 & 886 & 887 & 889 & 890 & 891 & 892 & 893 & 894 & 896 & 897 & 31 \\
32 & 883 & 884 & 886 & 857 & 885 & 889 & 890 & 892 & 893 & 894 & 32 \\
33 & 880 & 882 & 883 & 884 & 885 & 886 & 887 & 889 & 890 & 891 & 33 \\
34 & 878 & 879 & 880 & 881 & 882 & 883 & 885 & 886 & 887 & 890 & 34 \\
35 & 875 & 876 & 877 & 878 & 879 & 880 & 882 & 883 & 884 & 885 & 35 \\
\hline 36 & 872 & 873 & 874 & 875 & 877 & 878 & 879 & 880 & 881 & 882 & 36 \\
37 & 869 & 870 & 871 & 873 & 874 & 875 & 876 & 877 & 878 & 879 & 37 \\
35 & 866 & 867 & 869 & 870 & 871 & 872 & 873 & 874 & 875 & 877 & 38 \\
39 & 863 & 865 & 866 & 867 & 868 & 669 & 870 & 871 & 873 & 874 & 39 \\
40 & 861 & 862 & 867 & 864 & 865 & 866 & 868 & 869 & 870 & 871 & 40 \\
\hline
\end{tabular}

標準狀態換算係數表（四）

\begin{tabular}{|c|c|c|c|c|c|c|c|c|c|c|c|c|}
\hline $\begin{array}{l}\text { 氟臂 } \\
\text { 氣溫 }\end{array}$ & 760 & 761 & 762 & 768 & 764 & 765 & 766 & 767 & 768 & 769 & 770 & 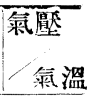 \\
\hline 0 & 1.000 & 1.001 & 1.003 & 1.004 & 1005 & $1.00 \%$ & 1.008 & 1.009 & 1.010 & 1.012 & 1.013 & 0 \\
\hline 1 & 996 & 998 & 999 & 1.000 & 1.002 & 1.003 & 1.004 & 1.005 & 1.007 & 1.008 & 1.009 & 1 \\
\hline 2 & 998 & 994 & 995 & 997 & 998 & 999 & 1.001 & 1.002 & 1.003 & 1.004 & 1.006 & 2 \\
\hline 3 & 989 & 990 & 992 & 993 & 994 & 996 & 997 & 998 & 999 & 1.000 & 1.002 & 3 \\
\hline 4 & 986 & 987 & 988 & 989 & 991 & 992 & 993 & 995 & 996 & 997 & 998 & 4 \\
\hline 5 & 982 & 983 & 985 & 986 & 987 & 988 & 990 & 991 & 992 & 994 & 995 & 5 \\
\hline 6 & 978 & 980 & 981 & 982 & 984 & 985 & 986 & 987 & 989 & 890 & 991 & 6 \\
\hline 7 & 975 & 976 & 978 & 979 & 980 & 981 & 983 & 984 & 985 & 987 & 988 & 7 \\
\hline 8 & $97 \%$ & 973 & 974 & 975 & 977 & 978 & 979 & 980 & 982 & 988 & 984 & 8 \\
\hline 9 & 968 & 969 & 971 & 972 & 973 & 974 & 670 & 977 & 9 & 80 & 981 & 9 \\
\hline 10 & $96 \check{~}$ & 966 & 967 & 968 & 970 & 971 & 72 & $97: 3$ & 975 & 976 & 977 & 10 \\
\hline 11 & 961 & 963 & 964 & 965 & 966 & 96 & 96 & 970 & 97 & 973 & 14 & 11 \\
\hline 12 & 958 & 959 & 9 & 96 & 963 & 9 & 9 & 967 & 968 & 69 & 970 & 12 \\
\hline 13 & 954 & 956 & 95 & 958 & 960 & 96 & 962 & 963 & 965 & 966 & 967 & 13 \\
\hline 14 & 951 & 952 & 954 & 955 & 956 & 957 & 959 & 960 & 961 & 962 & 964 & 14 \\
\hline 15 & 948 & 949 & 950 & 952 & 953 & 954 & 955 & 957 & 958 & 959 & 960 & 15 \\
\hline 16 & 945 & 94 & 947 & 8 & 950 & 901 & 952 & 953 & 950 & 986 & 957 & 16 \\
\hline 17 & 941 & 943 & 944 & 945 & 946 & 948 & 949 & 950 & 951 & 952 & 954 & 17 \\
\hline 18 & 938 & 939 & 941 & 942 & 943 & 944 & 946 & $9 \cdot 47$ & 948 & 949 & 950 & 18 \\
\hline 19 & 935 & 936 & 93 & 939 & 940 & 94 & 942 & 943 & 9 & 04 & 947 & 19 \\
\hline 20 & 932 & 933 & 934 & 935 & 937 & 938 & 939 & 940 & 941 & 943 & 944 & 20 \\
\hline
\end{tabular}




\begin{tabular}{|c|c|c|c|c|c|c|c|c|c|c|c|c|}
\hline \multicolumn{4}{|c|}{440} & \multicolumn{4}{|l|}{ 附 } & \multicolumn{5}{|l|}{ 錄 } \\
\hline 21 & 929 & 930 & 931 & 932 & 933 & $93 \bar{\jmath}$ & 936 & 937 & 938 & 940 & 941 & 21 \\
\hline 22 & 925 & 927 & 928 & 929 & 930 & 931 & 933 & 934 & 935 & 936 & 938 & 22 \\
\hline 23 & 922 & 923 & 925 & 926 & 927 & 928 & 930 & 931 & 932 & 933 & 934 & 28 \\
\hline 24 & 919 & 920 & 922 & 923 & 924 & 925 & 926 & 928 & 929 & 930 & 931 & 24 \\
\hline 25 & 916 & 917 & 919 & 920 & 921 & 922 & 923 & 925 & 926 & 927 & 928 & 25 \\
\hline 26 & 913 & 914 & 915 & 917 & 918 & 919 & 920 & 921 & 923 & 924 & 925 & 26 \\
\hline 27 & 910 & 911 & 912 & 914 & 915 & 916 & 917 & 918 & 920 & 921 & 922 & 27 \\
\hline 28 & 907 & 908 & 909 & 911 & $9 \mid 2$ & 913 & $9 \mathrm{I} 4$ & 915 & 916 & 918 & 919 & 28 \\
\hline 29 & 904 & 905 & 906 & 908 & 909 & 910 & 911 & 912 & 913 & 915 & 916 & 29 \\
\hline 30 & 901 & 902 & 903 & 905 & 906 & 907 & 908 & 909 & 910 & 912 & 913 & 30 \\
\hline 31 & 898 & 899 & 900 & 902 & 903 & 904 & 905 & 906 & 907 & 909 & 910 & 31 \\
\hline 32 & 895 & 896 & 897 & 899 & 900 & 901 & 902 & 903 & 904 & 906 & 907 & 32 \\
\hline 33 & 892 & \$93 & ذ) & 896 & 897 & 898 & 899 & 900 & 902 & 903 & 904 & 33 \\
\hline 34 & 889 & 890 & 892 & 893 & 894 & 895 & 896 & 897 & 899 & 900 & 901 & 34 \\
\hline 35 & 886 & 887 & 889 & 890 & 891 & 892 & 893 & 894 & 896 & 897 & 898 & $3 j$ \\
\hline 36 & 884 & 885 & 886 & 887 & 888 & 889 & 890 & 892 & 893 & 894 & $\$ 95$ & 36 \\
\hline 37 & 881 & 882 & 883 & 884 & 885 & $8 s 6$ & 888 & 889 & 890 & 891 & 892 & 37 \\
\hline 38 & 878 & 879 & 880 & 881 & 882 & 884 & 885 & 886 & 887 & 888 & 889 & 38 \\
\hline 39 & 875 & 876 & 877 & 878 & 879 & 881 & 882 & 883 & 884 & 885 & 886 & 39 \\
\hline 40 & 872 & 873 & 374 & 876 & 877 & 878 & 879 & 880 & 881 & 883 & 884 & 40 \\
\hline
\end{tabular}

\section{二. 一酸化炭菜の鑑識及定量}

1. 鑑 諓

1・䤃化第一パラジウム紙法

監化第一パラジウム溶液を以て濡ほしたる滤紙片走次の定量に於ける方法に 從ひ可檢空氣觉捕集せる壜中に迅速に奬垂し密栓し20-30 分間放置す心゙し此 際湑紙黑變する時は一酸化炭素存在の疑むるものとす.

陸化第一パラヂウム溶液の製法

監化第一パラヂウム $0.2 \mathrm{~g}$ 及醋酸ソーダ $1 . \mathrm{g}$ を水 $100 \mathrm{cc}$ に溶解光を遮り貯 ふべし.

口. 血液法

約 10 倍に稀釋せる新鮮なる血液 $10 \mathrm{cc}$ 中に豫め濃厚ナトロン涤液中芷通過 せしめたる可檢空氣約 $5 l$ を通じ分光器を用ひて之を檢すべし此場合 D 及 $\mathrm{E}$ 線の間に 2 條の吸收線を認め之に硫化 アンモン溶液を混和し放置して再 


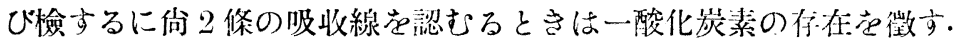

2. 定 量

本定量には次の裝置及試樂觉要す。

裝置

1. 捕莱㬡

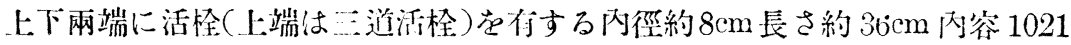

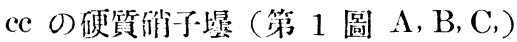

口. 酸化管

側管を侍する徑約 $3 \mathrm{~cm}$ 萌さ約 $21 \mathrm{~cm}$ のU字管に純無水ヨード酸 $\left(\mathrm{J}_{2} \mathrm{O}_{5}\right) 30$ -

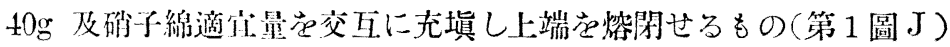

八. 吸收管:

a. 乾燥用䠗化カルシウム約 $50 \mathrm{~g}$ 及ソーダ石灰約 $100 \mathrm{~g}$ を U 字管の兩脚に 硝子綿范以て區分し充堑し上端を签閉せるもの(第 1 圖 $\mathrm{N}$ )

b. 小堍狀金羁アンチモン約 $350 \mathrm{~g}$ 及硝子綿の適宜量を交互にU 字管に充

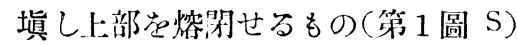

c. 米粒大の站吸收用活性炭素約 $100 \mathrm{~g}$ 觉徑約 $3 \mathrm{~cm}$ 長さ $21 \mathrm{~cm}$ の二重管 に光垻し其の兩端に硝子綿栓觉施せるもの(第 1 圖 $\mathrm{K}$ )

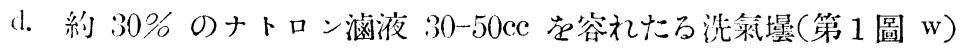

\section{試 啉}

1.バリツト液

精製水酸化バリウム $3.5 \mathrm{~g}$ 及籃化バリウム $6.5 \mathrm{~g}$ 定水に溶解し全量を 1 とな すべし.

本液は㷇酸定量に於けると同㥞注意して貯ふ心゙し.

口. 佂酸液

純苳酸 $\left.\underset{\mathrm{COOH}}{(\mathrm{COOH}}+2 \mathrm{H}_{2} \mathrm{O}\right) 1.412 \mathrm{~g}$ を水に溶解し全量を 1 とななべし.

本液 1cc は標準狀態に於ける炭酸 $\left(\mathrm{CO}_{2}\right) \quad 0.25 \mathrm{cc}$ に相當す.

檢體捕集方法

水を充したる捕氣嚗を現場に於て重直に保ち先づ上端の活栓を回轉し側管によ り壜の內外を連通せしめ次に下部の活栓を開き静に內部の水を全く流出せしめ 
たる後上下の活栓を閉づべし或は炭酸定量の場合に於ける如く錨觉以て探集す， るも可なり又多數の檢體を同時に捕集せんとするにはゴム管を以て數筒の捕筆

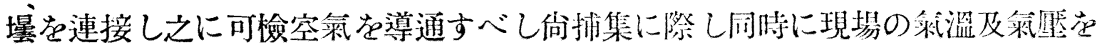
测定するを要す。

可檢空氣中にメタン,エチレン,アセチレン, 硫化水素, アンモニア管存在の長あ

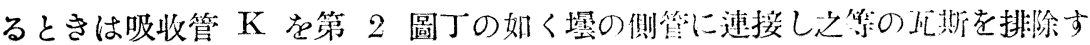
ベし.

實 施 法

前上玟置の各部を厚壁のゴム管を以て第 1 圖の如く速絡し酸化管 Jは汕浴中に在

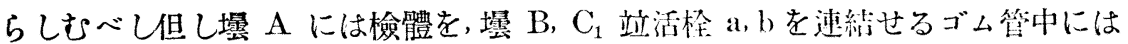
水を全霂せるものなり.

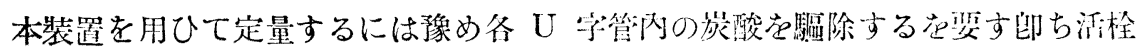
$\mathrm{H}$ を第 2 圖甲の位置を取らしめ $\mathrm{hh}^{\prime}$ を通じてナトロン涵液を谷れたる洗氣嚗 W

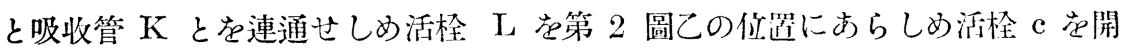
き $\mathrm{C}_{1}$ 中の水を流出せしめ殆ど流出し終らば挾塞子 $\mathrm{p}$ を以て $l$ 部を閉塞し再び

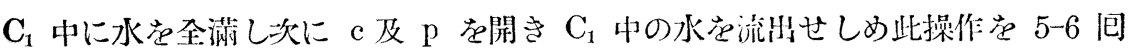
反復したる後更に $\mathrm{C}_{1}$ 中に水を全霂し $\mathrm{p}$ を以て $l$ 部荧閉ぢ活栓 $\mathrm{H}$ を第 2 圆丙

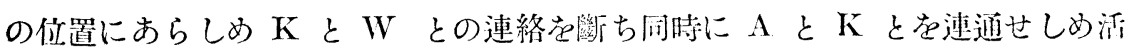
栓 $\mathrm{b}$ 及挾塞子 $\mathrm{p}$ を開き油浴觉 130-105 度に加熱し活栓 $\mathrm{a}$ 及 $\mathrm{c}$ ⿸尸同時に開き $\mathrm{B}$ 及 $\mathrm{C}_{1}$ 中の水を徐々（30分以上）に流下せしむべし但し $\mathrm{C}_{1}$ に於ける水の流下 は $\mathrm{B}$ に比し稍々速なるを要す $\mathrm{C}_{1}$ 中の水將に流出し終らんとするに至り活栓

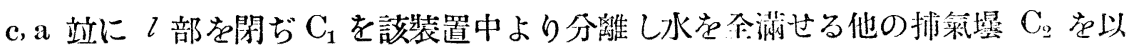
て置換し $\mathrm{C}_{2}$ の下部活栓站 $\mathrm{p}$, a を開きて $\mathrm{C}_{2}$ 中の水を流出せしめ $\mathrm{A}$ 中に水充 淽せんとするに至るや直に $\mathrm{a}$ を閉ぢ活栓 $\mathrm{H}$ を第 2 圖甲の位置を取らしめ $\mathrm{C}_{2}$ 中 の水將に流出し終らんとするに至り $\mathrm{C}_{1}$ の場合に於けると同樣にえを分蜼し更に 水を全滿せる捕氣壜 $\mathrm{C}_{3}$ 及 $\mathrm{C}_{4}$ を以て順次同樣に操作すべし. 前項に得たる壜 $\mathrm{C}_{1}, \mathrm{C}_{2}, \mathrm{C}_{3}$ 及 $\mathrm{C}_{4}$ 中にバリツト液各 $20 \mathrm{ce}$ を速に注加し善く振湦 すること 15 分以上に及びたる後蓚酸液を以を滴定すべし（標示藥フェノールフ タレイン溶液) 


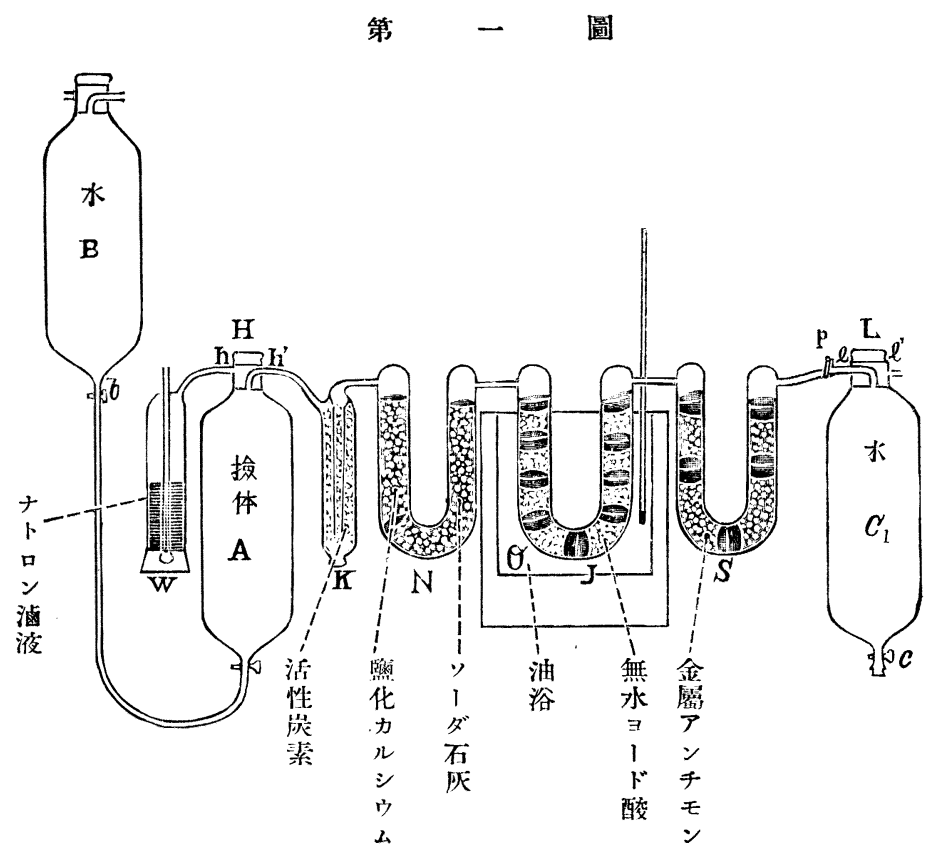

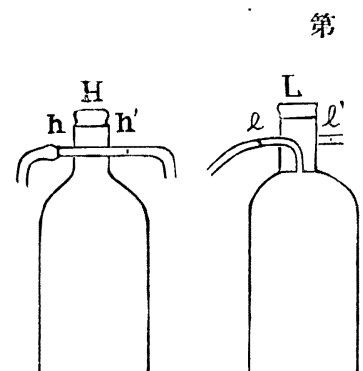

中1

乙

$$
=\quad \text { 圖 }
$$

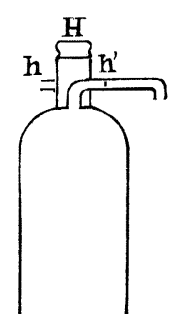

丙

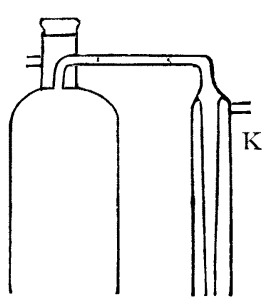

丁

立に要せし葆酸液量を夫々 $\mathrm{V}_{1}, \mathrm{~V}_{2}, \mathrm{~V}_{3}$, 及 $\mathrm{V}_{4} \mathrm{cc}$ とし同時に「バリット液 $20 \mathrm{cc} に$

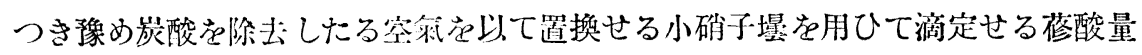
をV V とすれば可檢空莱中の一酸化炭素含量を算定する式次の如し

$$
\text { 一酸化菼素含量 }(\mathrm{ce} / \mathrm{L})=\frac{\mathrm{K} \times 1000}{\mathrm{~V}_{0}}
$$

式中 $\mathrm{K}$ は $4 \mathrm{~V}-\left(\mathrm{V}_{1}+\mathrm{V}_{2}+\mathrm{V}_{3}+\mathrm{V}_{4}\right) \times \frac{1020}{1000}$ より附表に照して得たる標準狀態 に於ける炭酸の cc 數, Voは捕集時に於ける籍溫, 匊壓より附表に照して得たる 標準狀態に撸算せる可憸空莱の ce 數なり. 


$$
\text { 筫 三 表 }
$$

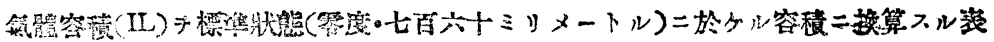

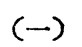

\begin{tabular}{|c|c|c|c|c|c|c|c|c|c|c|c|}
\hline 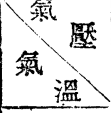 & 730 & 731 & 732 & 733 & 734 & 735 & 736 & 737 & 738 & 739 & 㵋 \\
\hline $\begin{array}{l}0 \\
\vdots \\
2 \\
8 \\
8 \\
4 \\
5\end{array}$ & $\begin{array}{l}960 \\
957 \\
954 \\
950 \\
947 \\
943\end{array}$ & $\begin{array}{l}952 \\
958 \\
955 \\
951 \\
948 \\
945\end{array}$ & $\begin{array}{l}963 \\
960 \\
956 \\
9.53 \\
949 \\
946\end{array}$ & $\begin{array}{l}964 \\
961 \\
957 \\
954 \\
951 \\
947\end{array}$ & $\begin{array}{l}956 \\
962 \\
959 \\
955 \\
952 \\
948\end{array}$ & $\begin{array}{l}967 \\
964 \\
960 \\
957 \\
953 \\
950\end{array}$ & $\begin{array}{l}968 \\
965 \\
961 \\
958 \\
955 \\
951\end{array}$ & $\begin{array}{l}970 \\
966 \\
963 \\
959 \\
956 \\
952\end{array}$ & $\begin{array}{l}971 \\
967 \\
964 \\
960 \\
957 \\
954\end{array}$ & $\begin{array}{l}972 \\
969 \\
965 \\
962 \\
958 \\
955\end{array}$ & $\begin{array}{l}0 \\
1 \\
2 \\
3 \\
4 \\
5\end{array}$ \\
\hline $\begin{array}{r}6 \\
7 \\
8 \\
9 \\
10\end{array}$ & $\begin{array}{l}940 \\
937 \\
933 \\
930 \\
927\end{array}$ & $\begin{array}{l}941 \\
938 \\
934 \\
931 \\
928\end{array}$ & $\begin{array}{l}942 \\
939 \\
936 \\
932 \\
929\end{array}$ & $\begin{array}{l}944 \\
940 \\
937 \\
934 \\
930\end{array}$ & $\begin{array}{l}945 \\
942 \\
933 \\
535 \\
932\end{array}$ & $\begin{array}{l}946 \\
94: \\
940 \\
936 \\
933\end{array}$ & $\begin{array}{l}948 \\
944 \\
941 \\
938 \\
934\end{array}$ & $\begin{array}{l}949 \\
946 \\
942 \\
939 \\
935\end{array}$ & $\begin{array}{l}950 \\
947 \\
943 \\
940 \\
937\end{array}$ & $\begin{array}{l}951 \\
948 \\
945 \\
941 \\
9: 38\end{array}$ & $\begin{array}{r}6 \\
7 \\
8 \\
9 \\
10\end{array}$ \\
\hline $\begin{array}{l}11 \\
12 \\
13 \\
14 \\
15\end{array}$ & $\begin{array}{l}923 \\
920 \\
917 \\
914 \\
910\end{array}$ & $\begin{array}{l}925 \\
921 \\
913 \\
915 \\
912\end{array}$ & $\begin{array}{l}926 \\
923 \\
919 \\
916 \\
913\end{array}$ & $\begin{array}{l}927 \\
924 \\
921 \\
917 \\
914\end{array}$ & $\begin{array}{l}928 \\
925 \\
922 \\
919 \\
915\end{array}$ & $\begin{array}{l}930 \\
926 \\
923 \\
920 \\
917\end{array}$ & $\begin{array}{l}931 \\
928 \\
924 \\
921 \\
918\end{array}$ & $\begin{array}{l}932 \\
929 \\
926 \\
922 \\
919\end{array}$ & $\begin{array}{l}933 \\
930 \\
927 \\
924 \\
920\end{array}$ & $\begin{array}{l}935 \\
981 \\
928 \\
925 \\
922\end{array}$ & $\begin{array}{l}11 \\
12 \\
13 \\
14 \\
15\end{array}$ \\
\hline $\begin{array}{l}16 \\
17 \\
18 \\
19 \\
20\end{array}$ & $\begin{array}{l}907 \\
901 \\
901 \\
893 \\
890\end{array}$ & $\begin{array}{l}909 \\
905 \\
902 \\
899 \\
896\end{array}$ & $\begin{array}{l}910 \\
907 \\
904 \\
900 \\
597\end{array}$ & $\begin{array}{l}911 \\
908 \\
905 \\
902 \\
899\end{array}$ & $\begin{array}{l}912 \\
909 \\
906 \\
203 \\
900\end{array}$ & $\begin{array}{l}914 \\
910 \\
907 \\
904 \\
901\end{array}$ & $\begin{array}{l}915 \\
912 \\
909 \\
906 \\
902\end{array}$ & $\begin{array}{l}916 \\
913 \\
910 \\
9 n 7 \\
903\end{array}$ & $\begin{array}{l}917 \\
914 \\
911 \\
908 \\
905\end{array}$ & $\begin{array}{l}919 \\
915 \\
912 \\
909 \\
906\end{array}$ & $\begin{array}{l}16 \\
17 \\
18 \\
19 \\
20\end{array}$ \\
\hline $\begin{array}{l}21 \\
22 \\
23 \\
24 \\
25\end{array}$ & $\begin{array}{l}892 \\
889 \\
886 \\
883 \\
880\end{array}$ & $\begin{array}{l}893 \\
890 \\
887 \\
884 \\
381\end{array}$ & $\begin{array}{l}894 \\
891 \\
888 \\
885 \\
882\end{array}$ & $\begin{array}{l}896 \\
893 \\
889 \\
886 \\
884\end{array}$ & $\begin{array}{l}897 \\
894 \\
891 \\
888 \\
885\end{array}$ & $\begin{array}{l}898 \\
895 \\
892 \\
889 \\
886\end{array}$ & $\begin{array}{l}899 \\
896 \\
893 \\
890 \\
857\end{array}$ & $\begin{array}{l}900 \\
897 \\
894 \\
891 \\
888\end{array}$ & $\begin{array}{l}902 \\
899 \\
896 \\
893 \\
890\end{array}$ & $\begin{array}{l}903 \\
900 \\
897 \\
894 \\
891\end{array}$ & $\begin{array}{l}21 \\
22 \\
23 \\
24 \\
25\end{array}$ \\
\hline $\begin{array}{l}26 \\
27 \\
28 \\
29 \\
30\end{array}$ & $\begin{array}{l}877 \\
874 \\
871 \\
868 \\
865\end{array}$ & $\begin{array}{l}878 \\
875 \\
872 \\
869 \\
867\end{array}$ & $\begin{array}{l}879 \\
876 \\
873 \\
871 \\
868\end{array}$ & $\begin{array}{l}881 \\
878 \\
875 \\
872 \\
869\end{array}$ & $\begin{array}{l}882 \\
879 \\
876 \\
873 \\
870\end{array}$ & $\begin{array}{l}883 \\
880 \\
877 \\
874 \\
871\end{array}$ & $\begin{array}{l}884 \\
881 \\
878 \\
875 \\
873\end{array}$ & $\begin{array}{l}885 \\
382 \\
879 \\
877 \\
874\end{array}$ & $\begin{array}{l}887 \\
884 \\
881 \\
878 \\
875\end{array}$ & $\begin{array}{l}888 \\
885 \\
882 \\
879 \\
876\end{array}$ & $\begin{array}{l}26 \\
2 . \\
28 \\
29 \\
30\end{array}$ \\
\hline $\begin{array}{l}31 \\
32 \\
32 \\
34 \\
35\end{array}$ & $\begin{array}{l}863 \\
860 \\
857 \\
854 \\
851\end{array}$ & $\begin{array}{l}864 \\
861 \\
855 \\
855 \\
852\end{array}$ & $\begin{array}{l}865 \\
862 \\
859 \\
856 \\
854\end{array}$ & $\begin{array}{l}866 \\
863 \\
850 \\
358 \\
855\end{array}$ & $\begin{array}{l}867 \\
864 \\
862 \\
859 \\
856\end{array}$ & $\begin{array}{l}868 \\
866 \\
863 \\
860 \\
857\end{array}$ & $\begin{array}{l}870 \\
867 \\
864 \\
861 \\
858\end{array}$ & $\begin{array}{l}871 \\
868 \\
865 \\
862 \\
859\end{array}$ & $\begin{array}{l}872 \\
869 \\
866 \\
863 \\
861\end{array}$ & $\begin{array}{l}873 \\
870 \\
868 \\
865 \\
862\end{array}$ & $\begin{array}{l}31 \\
32 \\
33 \\
34 \\
35\end{array}$ \\
\hline $\begin{array}{l}36 \\
37 \\
88 \\
39 \\
40\end{array}$ & $\begin{array}{l}849 \\
846 \\
843 \\
840 \\
838\end{array}$ & $\begin{array}{l}850 \\
847 \\
844 \\
842 \\
839\end{array}$ & $\begin{array}{l}851 \\
848 \\
845 \\
843 \\
340\end{array}$ & $\begin{array}{l}852 \\
849 \\
847 \\
844 \\
841\end{array}$ & $\begin{array}{l}853 \\
850 \\
848 \\
845 \\
842\end{array}$ & $\begin{array}{l}854 \\
852 \\
849 \\
846 \\
843\end{array}$ & $\begin{array}{l}856 \\
853 \\
850 \\
847 \\
845\end{array}$ & $\begin{array}{l}857 \\
854 \\
851 \\
848 \\
846\end{array}$ & $\begin{array}{l}858 \\
855 \\
852 \\
850 \\
847\end{array}$ & $\begin{array}{l}859 \\
856 \\
854 \\
851 \\
848\end{array}$ & $\begin{array}{l}36 \\
37 \\
38 \\
99 \\
40\end{array}$ \\
\hline
\end{tabular}


第 三㳖

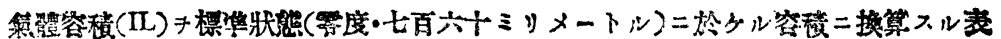

(二)

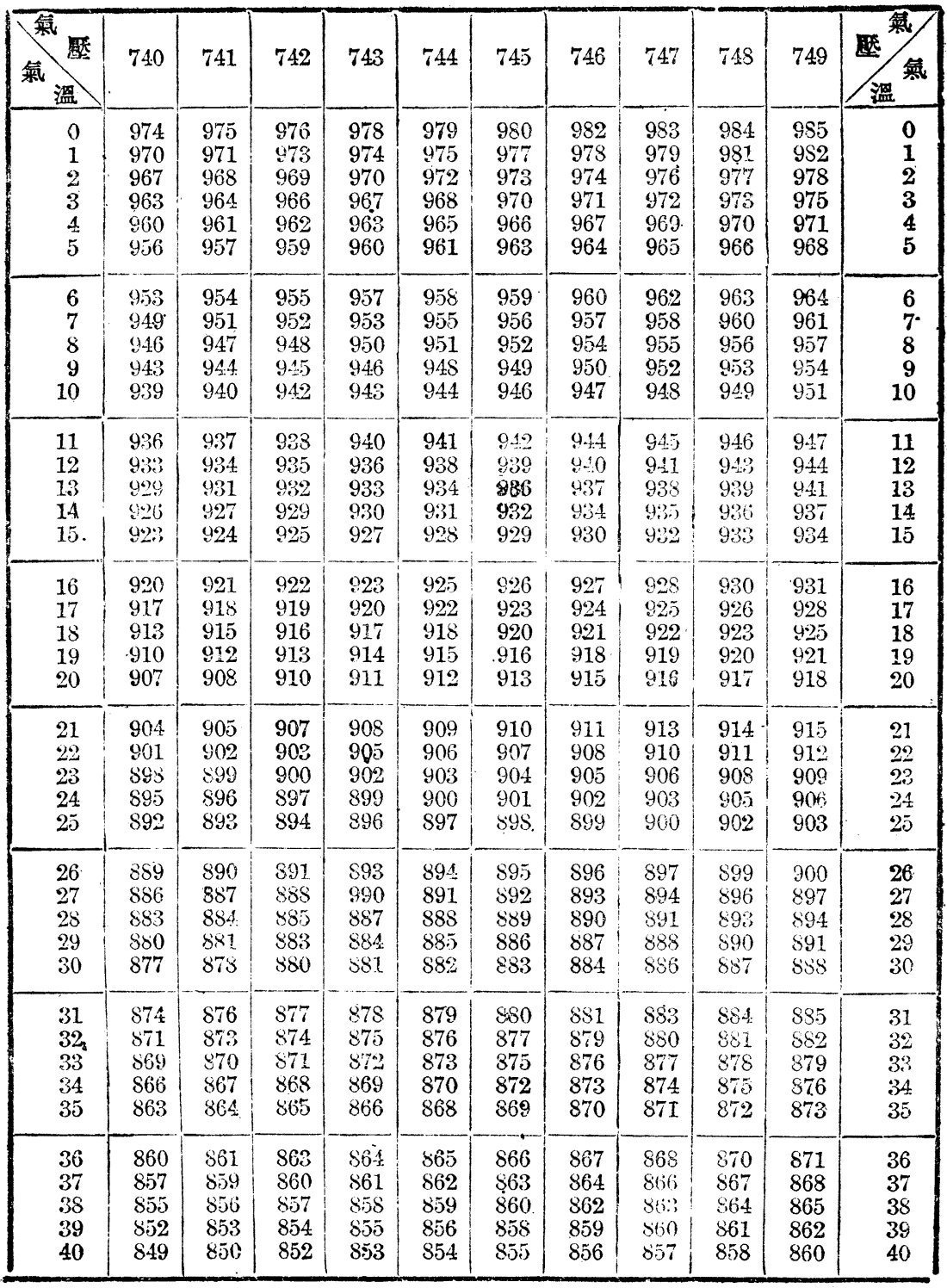




\section{策 三 表}

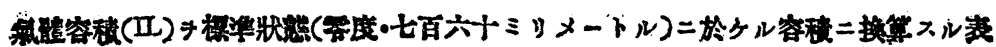

$$
\text { (三) }
$$

\begin{tabular}{|c|c|c|c|c|c|c|c|c|c|c|c|}
\hline 氣 & 750 & 751 & 752 & 753 & 754 & 755 & 756 & 757 & 758 & 759 & 㗨 \\
\hline $\begin{array}{l}0 \\
1 \\
2 \\
3 \\
4 \\
5\end{array}$ & $\begin{array}{l}987 \\
983 \\
980 \\
976 \\
973 \\
969\end{array}$ & $\begin{array}{l}988 \\
985 \\
981 \\
977 \\
974 \\
970\end{array}$ & $\begin{array}{l}989 \\
986 \\
982 \\
979 \\
975 \\
972\end{array}$ & $\begin{array}{l}991 \\
987 \\
984 \\
980 \\
976 \\
973\end{array}$ & $\begin{array}{l}992 \\
988 \\
985 \\
981 \\
978 \\
974 .\end{array}$ & $\begin{array}{l}993 \\
990 \\
986 \\
983 \\
979 \\
976\end{array}$ & $\begin{array}{l}994 \\
991 \\
987 \\
984 \\
980 \\
377\end{array}$ & $\begin{array}{l}996 \\
992 \\
989 \\
985 \\
982 \\
978\end{array}$ & $\begin{array}{l}997 \\
994 \\
990 \\
986 \\
983 \\
979\end{array}$ & $\begin{array}{l}999 \\
995 \\
991 \\
988 \\
984 \\
981\end{array}$ & $\begin{array}{l}0 \\
1 \\
2 \\
3 \\
4 \\
5\end{array}$ \\
\hline $\begin{array}{r}6 \\
7 \\
8 \\
9 \\
10\end{array}$ & $\begin{array}{l}966 \\
962 \\
959 \\
955 \\
952\end{array}$ & $\begin{array}{l}967 \\
964 \\
960 \\
957 \\
953\end{array}$ & $\begin{array}{l}968 \\
965 \\
961 \\
958 \\
954\end{array}$ & $\begin{array}{l}969 \\
966 \\
963 \\
959 \\
956\end{array}$ & $\begin{array}{l}971 \\
967 \\
964 \\
960 \\
957\end{array}$ & $\begin{array}{l}972 \\
968 \\
965 \\
962 \\
958\end{array}$ & $\begin{array}{l}973 \\
970 \\
966 \\
963 \\
960\end{array}$ & $\begin{array}{l}975 \\
971 \\
968 \\
964 \\
961\end{array}$ & $\begin{array}{l}976 \\
973 \\
969 \\
966 \\
962\end{array}$ & $\begin{array}{r}977 \\
974 \\
970 \\
.967 \\
963\end{array}$ & $\begin{array}{r}6 \\
7 \\
8 \\
9 \\
10\end{array}$ \\
\hline $\begin{array}{l}11 \\
12 \\
13 \\
14 \\
15\end{array}$ & $\begin{array}{l}949 \\
945 \\
942 \\
939 \\
935\end{array}$ & $\begin{array}{l}950 \\
946 \\
943 \\
940 \\
937\end{array}$ & $\begin{array}{l}951 \\
948 \\
944 \\
941 \\
938\end{array}$ & $\begin{array}{l}952 \\
949 \\
946 \\
942 \\
939\end{array}$ & $\begin{array}{l}954 \\
950 \\
947 \\
944 \\
940\end{array}$ & $\begin{array}{l}955 \\
952 \\
948 \\
945 \\
942\end{array}$ & $\begin{array}{l}956 \\
953 \\
949 \\
946 \\
943\end{array}$ & $\begin{array}{l}957 \\
954 \\
951 \\
947 \\
944\end{array}$ & $\begin{array}{l}959 \\
955 \\
952 \\
949 \\
945\end{array}$ & $\begin{array}{l}960 \\
957 \\
953 \\
950 \\
947\end{array}$ & $\begin{array}{l}11 \\
12 \\
13 \\
14 \\
15\end{array}$ \\
\hline $\begin{array}{l}16 \\
17 \\
18 \\
19 \\
20\end{array}$ & $\begin{array}{l}932 \\
929 \\
926 \\
923 \\
919\end{array}$ & $\begin{array}{l}933 \\
930 \\
927 \\
924 \\
921\end{array}$ & $\begin{array}{l}935 \\
931 \\
928 \\
925 \\
922\end{array}$ & $\begin{array}{l}936 \\
933 \\
930 \\
920 \\
923\end{array}$ & $\begin{array}{l}937 \\
934 \\
931 \\
927 \\
924\end{array}$ & $\begin{array}{l}938 \\
935 \\
932 \\
929 \\
\mathbf{2 6}\end{array}$ & $\begin{array}{l}940 \\
936 \\
933 \\
930 \\
927\end{array}$ & $\begin{array}{l}941 \\
938 \\
934 \\
931 \\
928\end{array}$ & $\begin{array}{l}942 \\
939 \\
936 \\
932 \\
929\end{array}$ & $\begin{array}{l}943 \\
940 \\
937 \\
934 \\
930\end{array}$ & $\begin{array}{l}16 \\
17 \\
18 \\
19 \\
20\end{array}$ \\
\hline $\begin{array}{l}21 \\
22 \\
23 \\
24 \\
25\end{array}$ & $\begin{array}{l}916 \\
913 \\
910 \\
907 \\
904\end{array}$ & $\begin{array}{l}918 \\
914 \\
911 \\
908 \\
905\end{array}$ & $\begin{array}{l}919 \\
916 \\
913 \\
909 \\
906\end{array}$ & $\begin{array}{l}920 \\
917 \\
914 \\
911 \\
908\end{array}$ & $\begin{array}{l}921 \\
918 \\
915 \\
912 \\
909\end{array}$ & $\begin{array}{l}922 \\
919 \\
916 \\
913 \\
910\end{array}$ & $\begin{array}{l}924 \\
921 \\
917 \\
914 \\
911\end{array}$ & $\begin{array}{l}925 \\
922 \\
919 \\
916 \\
912\end{array}$ & $\begin{array}{l}\$ 26 \\
923 \\
920 \\
917 \\
914\end{array}$ & $\begin{array}{l}927 \\
924 \\
921 \\
918 \\
915\end{array}$ & $\begin{array}{l}21 \\
22 \\
23 \\
24 \\
25\end{array}$ \\
\hline $\begin{array}{l}26 \\
27 \\
23 \\
29 \\
30\end{array}$ & $\begin{array}{l}901 \\
898 \\
895 \\
892 \\
859\end{array}$ & $\begin{array}{l}902 \\
899 \\
896 \\
893 \\
890\end{array}$ & $\begin{array}{l}903 \\
900 \\
897 \\
894 \\
891\end{array}$ & $\begin{array}{l}405 \\
902 \\
899 \\
896 \\
893\end{array}$ & $\begin{array}{l}906 \\
903 \\
900 \\
597 \\
894\end{array}$ & $\begin{array}{l}907 \\
904 \\
901 \\
898 \\
895\end{array}$ & $\begin{array}{l}908 \\
905 \\
902 \\
899 \\
896\end{array}$ & $\begin{array}{l}909 \\
906 \\
903 \\
900 \\
897\end{array}$ & $\begin{array}{l}911 \\
908 \\
905 \\
902 \\
898\end{array}$ & $\begin{array}{l}912 \\
\dot{9} 09 \\
906 \\
908 \\
900\end{array}$ & $\begin{array}{l}26 \\
27 \\
28 \\
29 \\
30\end{array}$ \\
\hline $\begin{array}{l}31 \\
32 \\
33 \\
34 \\
35\end{array}$ & $\begin{array}{l}886 \\
883 \\
880 \\
878 \\
875\end{array}$ & $\begin{array}{l}887 \\
884 \\
832 \\
879 \\
876\end{array}$ & $\begin{array}{l}889 \\
880 \\
883 \\
580 \\
877\end{array}$ & $\begin{array}{l}890 \\
887 \\
884 \\
881 \\
878\end{array}$ & $\begin{array}{l}891 \\
888 \\
885 \\
882 \\
879\end{array}$ & $\begin{array}{l}892 \\
889 \\
886 \\
883 \\
880\end{array}$ & $\begin{array}{l}893 \\
890 \\
887 \\
885 \\
882\end{array}$ & $\begin{array}{l}894 \\
892 \\
889 \\
886 \\
883\end{array}$ & $\begin{array}{l}896 \\
893 \\
890 \\
887 \\
884\end{array}$ & $\begin{array}{l}897 \\
894 \\
891 \\
890 \\
885\end{array}$ & $\begin{array}{l}31 \\
32 \\
83 \\
84 \\
35\end{array}$ \\
\hline $\begin{array}{l}36 \\
37 \\
38 \\
39 \\
40\end{array}$ & $\begin{array}{l}872 \\
869 \\
866 \\
863 \\
861\end{array}$ & $\begin{array}{l}873 \\
870 \\
867 \\
865 \\
862\end{array}$ & $\begin{array}{l}874 \\
871 \\
869 \\
866 \\
863\end{array}$ & $\begin{array}{l}875 \\
873 \\
870 \\
867 \\
864\end{array}$ & $\begin{array}{l}877 \\
874 \\
871 \\
868 \\
865\end{array}$ & $\begin{array}{l}878 \\
875 \\
872 \\
869 \\
866\end{array}$ & $\begin{array}{l}879 \\
576 \\
873 \\
870 \\
868\end{array}$ & $\begin{array}{l}880 \\
877 \\
874 \\
871 \\
869\end{array}$ & $\begin{array}{l}881 \\
878 \\
875 \\
873 \\
870\end{array}$ & $\begin{array}{l}882 \\
879 \\
877 \\
574 \\
871\end{array}$ & $\begin{array}{l}36 \\
37 \\
38 \\
39 \\
40\end{array}$ \\
\hline
\end{tabular}




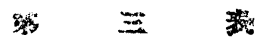

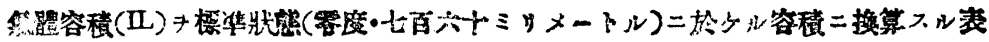

(国)

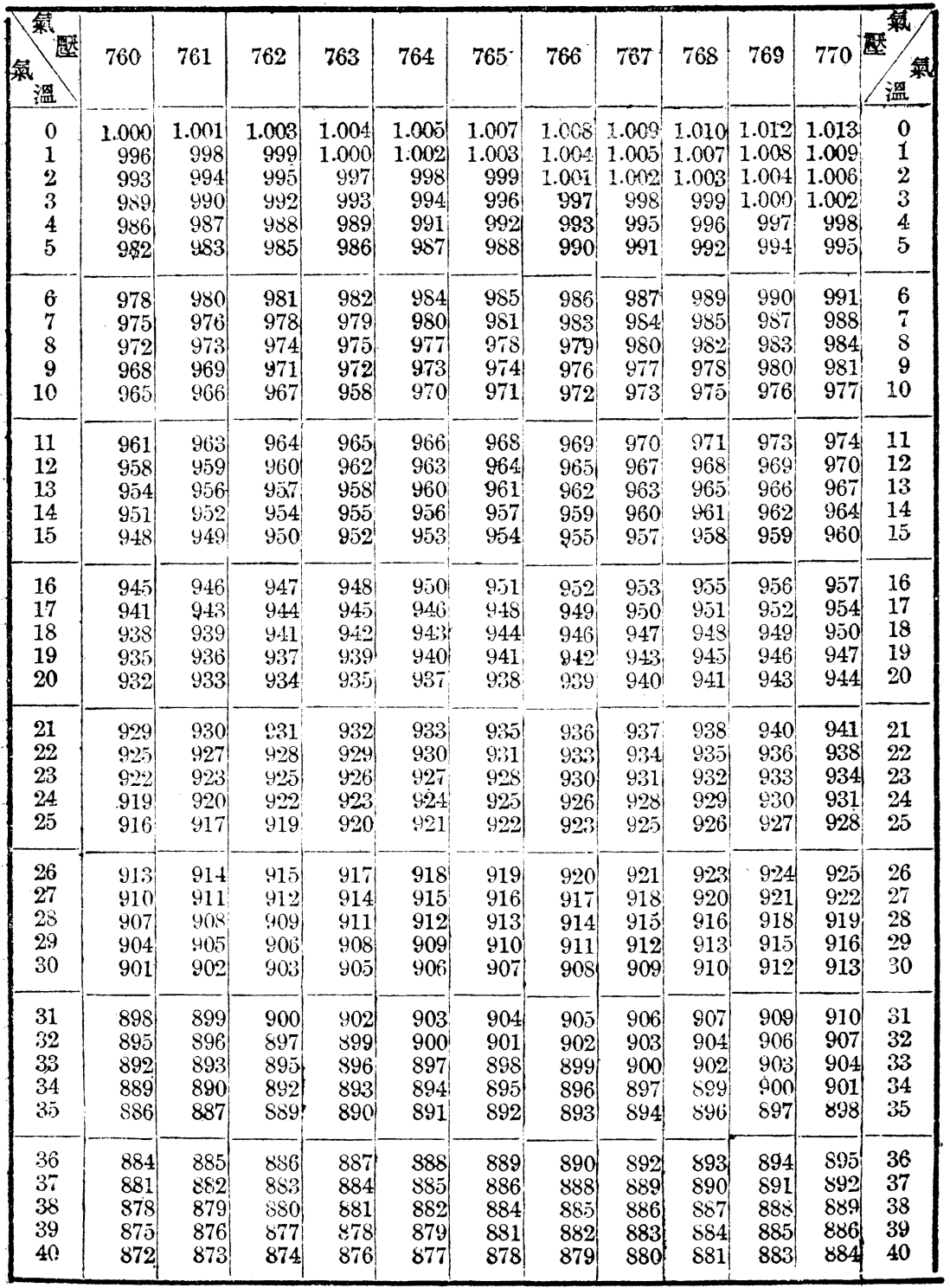




\begin{tabular}{|c|c|c|c|c|c|c|}
\hline \multirow{12}{*}{ 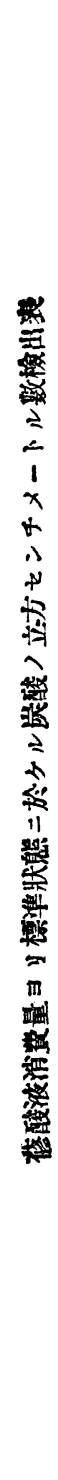 } & & 880.19 & สิลัตัต & 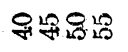 & 옹농유몬 & 우ㅇㅛㅛ \\
\hline & 오 & 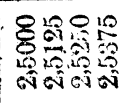 & 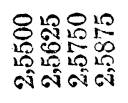 & 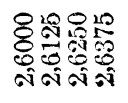 & 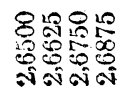 & 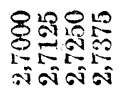 \\
\hline & $\infty$ & 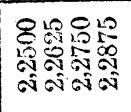 & 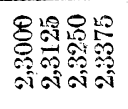 & 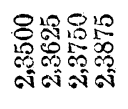 & 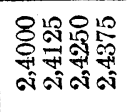 & 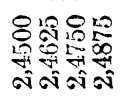 \\
\hline & $\infty$ & 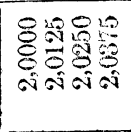 & 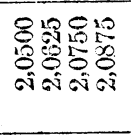 & 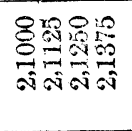 & 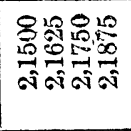 & 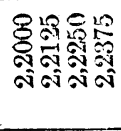 \\
\hline & $\infty$ & 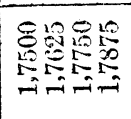 & 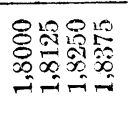 & 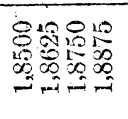 & 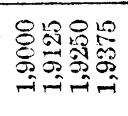 & 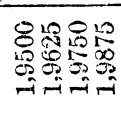 \\
\hline & 0 & 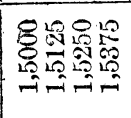 & 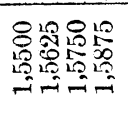 & 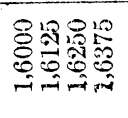 & 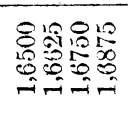 & 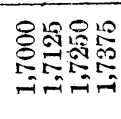 \\
\hline & $\infty$ & 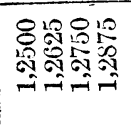 & 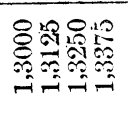 & 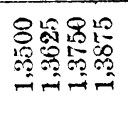 & 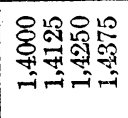 & 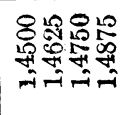 \\
\hline & + & 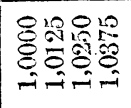 & 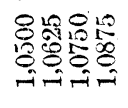 & 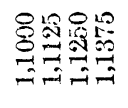 & 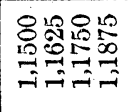 & 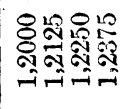 \\
\hline & $\infty$ & 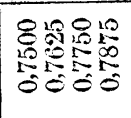 & 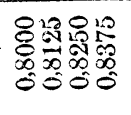 & 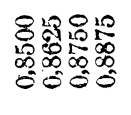 & 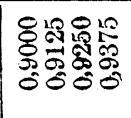 & 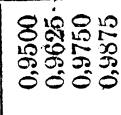 \\
\hline & $N$ & 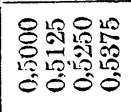 & 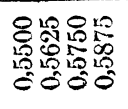 & 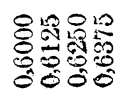 & 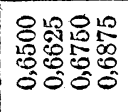 & 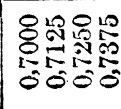 \\
\hline & -1 & 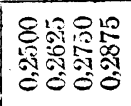 & 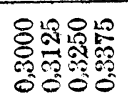 & 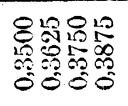 & 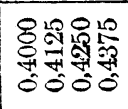 & 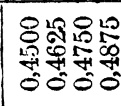 \\
\hline & & 8움 & 조ำ & 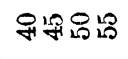 & 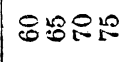 & $\triangle 1889$ \\
\hline
\end{tabular}




\section{○第十四同日本藥學會薬劑部長會}

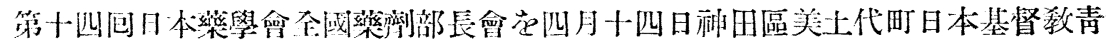

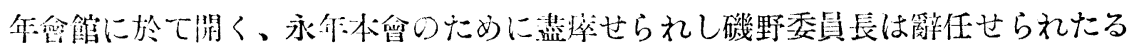
在以て杉非湲维氏推與せられて委过長となる。午前九時杉井委員長開會觉宣し議 事に入る。

翊 染

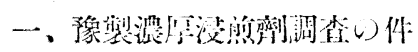

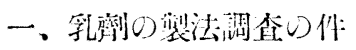

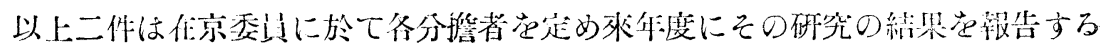

ことに胁定す。

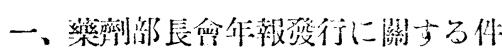

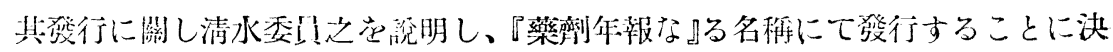
定市。

派岳

$\cdots$ 、坐藥處方例洞查の件:

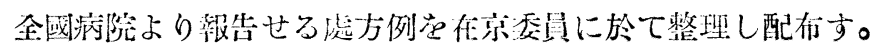

一、乳劑の一新裂法

奥 野 政 藏

一、日本案局方败正意見に對する解說

（刈米達夫 今野運治

一、コンヅランゴ皮裂劑中コンヅランギンの含量に就て

久 野渓一

一、アムプル入注射㧝の䍒查に就て 垂永茂

一、新㳄高基硕劑に就 往题報告

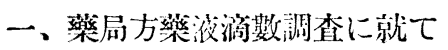

杉井䍭雄

一、アスピリンの研究報告

田中莪雄

一、同

江口作

一、同

今 野蓮治 


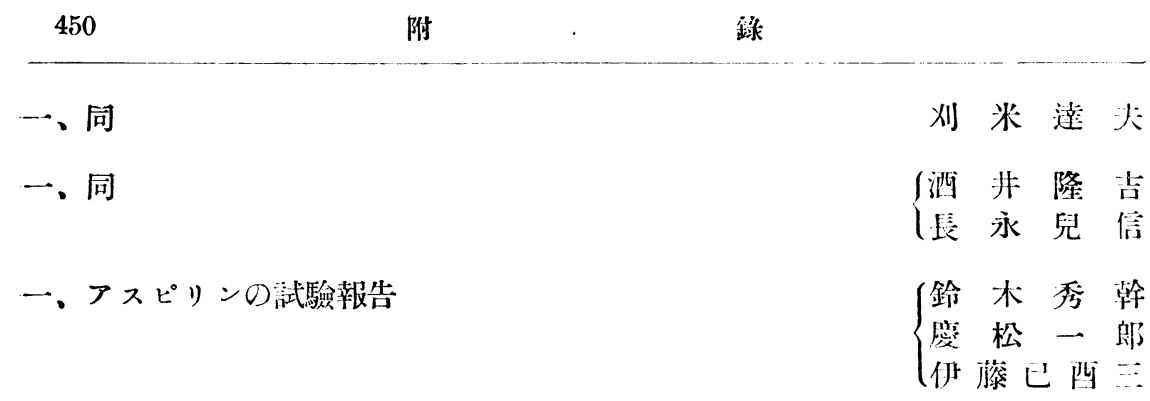

少立入委員よりアスピリンに關する報告ある豫定なりしも時润り都命上少略せ り。

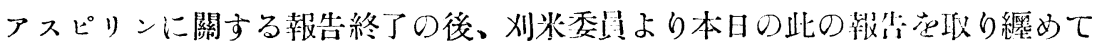

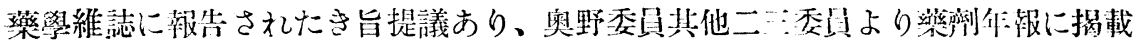
するを適當とする旨を述べられ結局在京委員に一任することに沈资せり。份䖴告 者は至急原稿军送られたき旨希望す。

講 演

一、藥㭊方藥品の試驗に就て 个 野運治 示 祬

…散藥用榬置瓶及投藥用點眼瓶供覽

一、考案调娈器械二三の偩覽

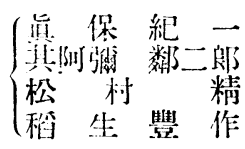
以上の研究報告及绾題報告は演者站に出席會員一闹熱心にして大に得る所り 午後四時閉會す。 


\section{藥劑部長會報告坐藥處方例表}

\section{坐 藥 處 方 例 表}

A 肛門坐劑（賦形藥カカ才脂 1.5-2.0）

\section{（1）監酸コカイン坐劑}

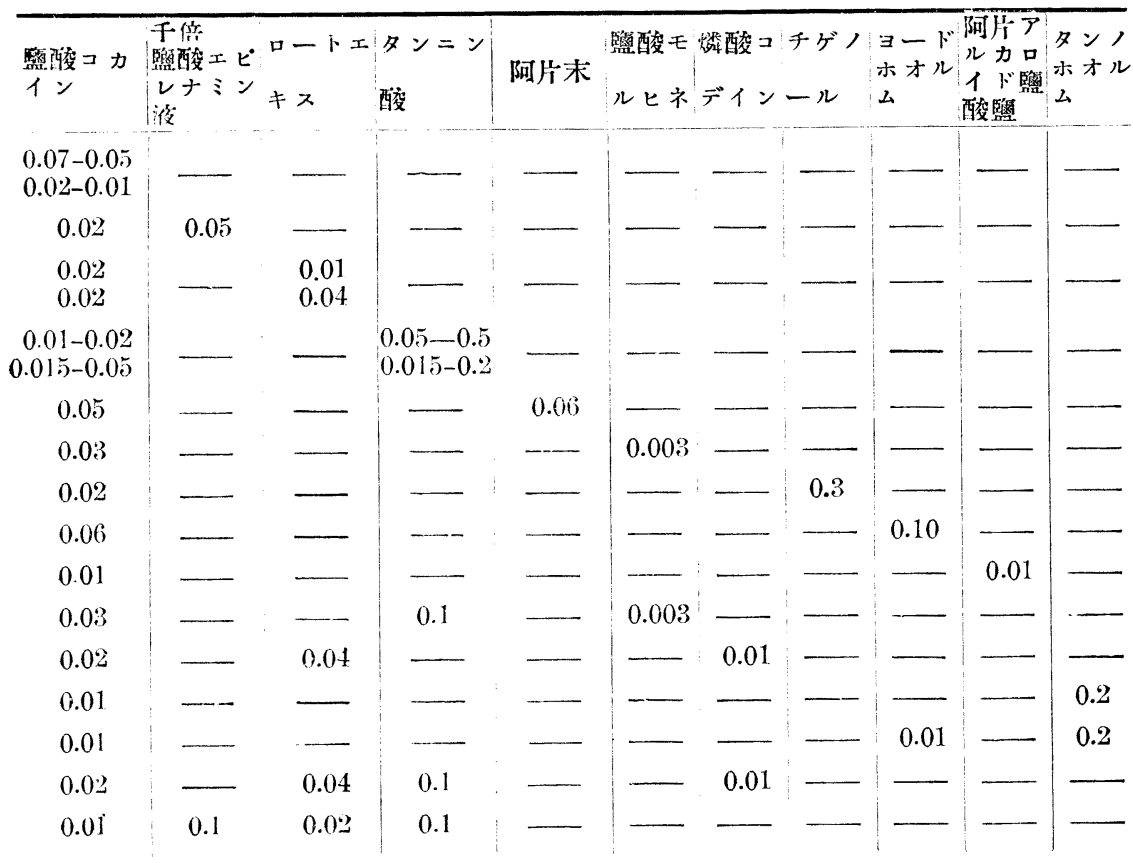

\section{（2）複方ロートエキス坐劑}

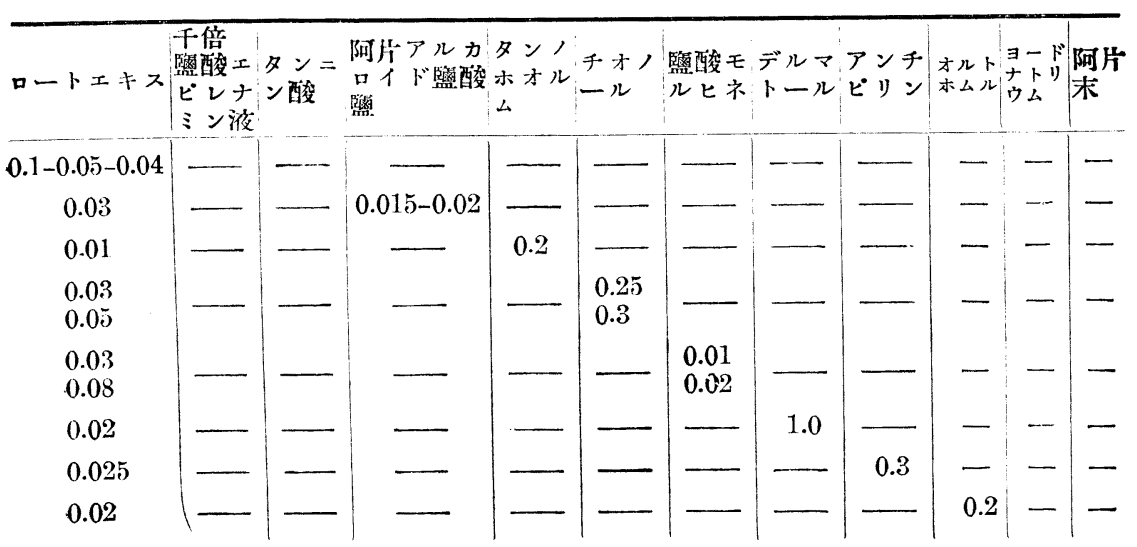




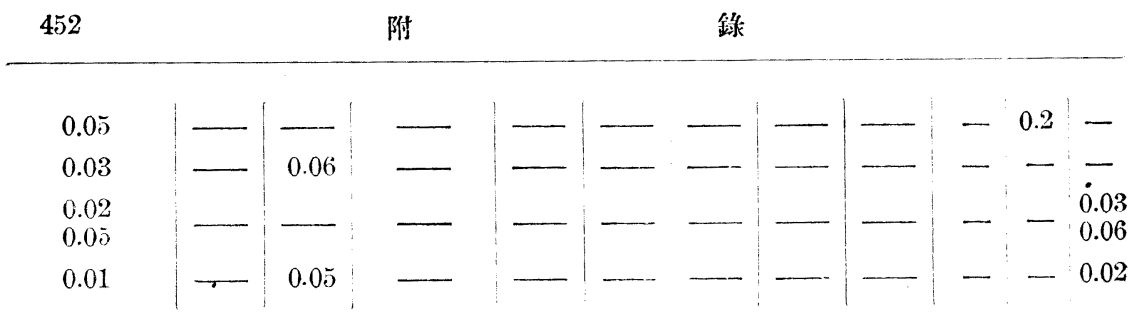

\section{（3）1ヒチオール坐劑}

\begin{tabular}{|c|c|c|c|c|}
\hline $\begin{array}{l}\text { イヒチオールスル } \\
\text { ホン䧑ンンモン }\end{array}$ & デルマトール & コロイド銀 & 燐酸コデイン & ョードホルム \\
\hline 0.1 & - & - & - & - \\
\hline 0.1 & 0.3 & - & - & - \\
\hline 0.3 & - & 0.1 & - & - \\
\hline 0.2 & - & - & 0.06 & - \\
\hline 0.1 & - & - & & 0.8 \\
\hline
\end{tabular}

\section{（4）タンニン酸坐劑}

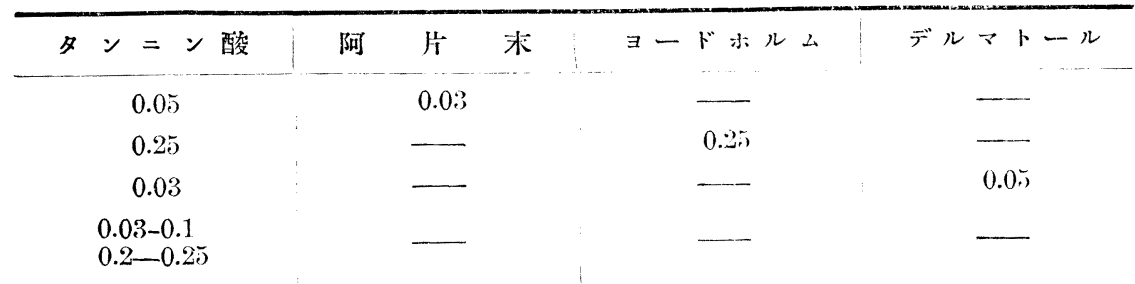

（5）アンチピリン坐劑

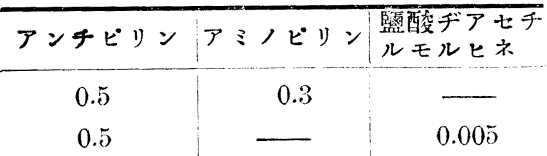

(6) 阿片肛 (7) ピチ (8) 次硝酸

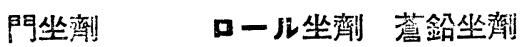
阿年林 $\begin{array}{lll}0.05 & 0.2 & 0.5 \\ 0.06 & \end{array}$

\section{（9）リスリン坐劑}

\begin{tabular}{c|c|c|c|c}
\hline グリセリン & ステアリン酸 & 重炭酸ソーダ & 炭酸ソーダ & 蒸 馏 水 \\
\hline 3.0 & 0.25 & - & 0.15 & - \\
\hline
\end{tabular}

B 尿道坐劑 (賦形藥力力才脂 $0.8-0.4$ )

\section{（1）コカイン坐劑}

\begin{tabular}{l|c|c|c|c}
\hline 醞酸コカイン & ロートエキス & タンンン酸 & 确 酸 亞 鉛 & ヨードホルム \\
\hline $\begin{array}{l}0.003-0.005 \\
0.015-0.02\end{array}$ & - & - & - & -
\end{tabular}




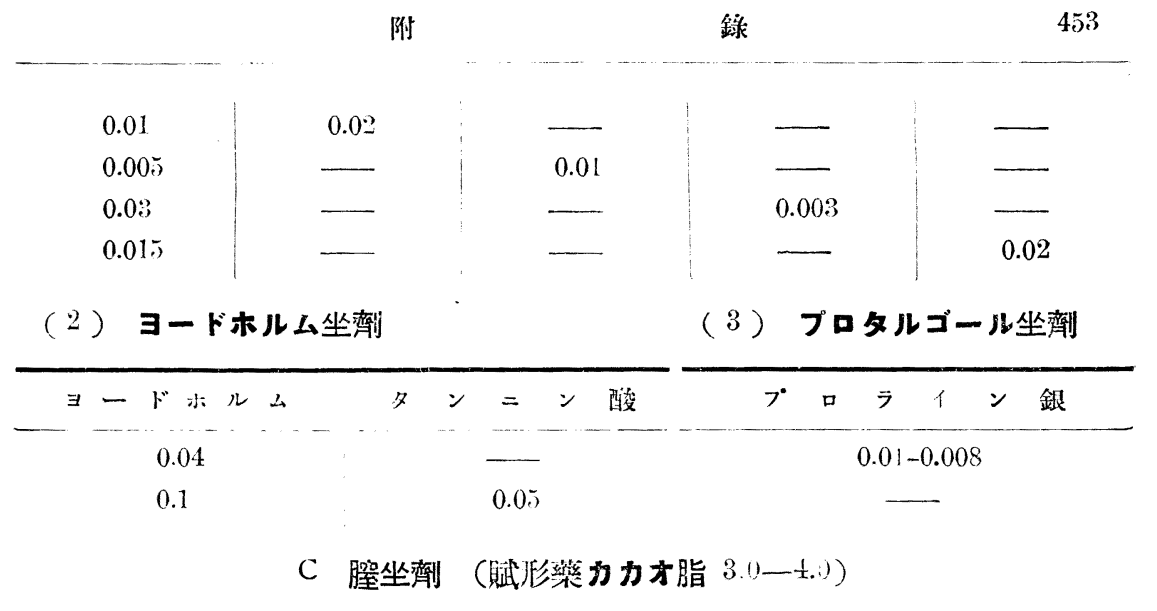

\section{（1）1ヒチオール腔球(チ3゙ノール文ハチ （2） ヨードカリ脽求} オノールチ念ム)

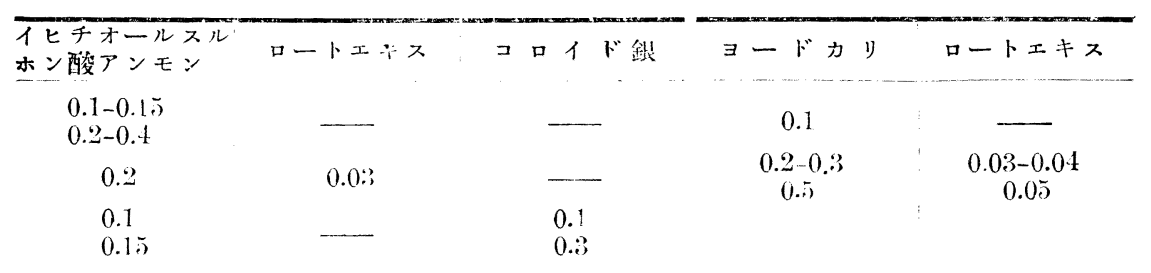

(3) コカイン胿球

（4）ロート（5）阿片腥球（6）タンニン エキス胑球酸胵球

\begin{tabular}{|c|c|c|c|c|c|}
\hline 監酸コカイン & ロートエキス & タンニン酸 & ロートエキス & 阿片 末 & タンニン酸 \\
\hline $\begin{array}{l}0.02 \\
0.0 ?\end{array}$ & $\begin{array}{l}0.03 \\
0.05 i\end{array}$ & - & 0.06 & $0.06-0.1$ & 0.1 \\
\hline 0.05 & - & 0.02 & & & \\
\hline
\end{tabular}

\section{局方藥品の試驗に就て}

今野運治

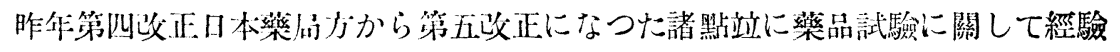
上不適になり易い土なる項目に就きてAの部罟けたのであるが弓續きBの部 より述べて參考に倛したいと思ふ.

Balsammm Copaivae コバイバルサム

二項中浴解菜として氷醋酸を加へだ分量は純アルコールと同量 $5 \mathrm{cc} て ゙$ 純アルコ 
一ルで澄明に溶けても氷醋酸で濁る場合が往々ある䗨の夾雜ではないらしい五項 グリュンバルサム夾雜試驗は四版の方法は不銃做なるを以て簡易にしてより銳儌 なる方法になしたのである六項の新加項は脂肪油又はバラフィン等の夾雜試驗で ある從來のアルコール不溶分の檢出站に不殓汕分の水醋酸浴解の項が删除された

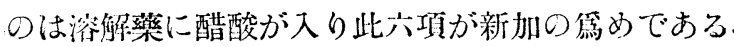

（注意） 臭氣不良. 純アルコール或は水醋酸に溶解するに泪濁强きものあり．又 アムモニア水に由て凝膠物を析出す.

Balsamum peruvianum ペルーバルサム

從來のチンナメインを檢出する項は其反憵確實ならす故に之を省き第五项とし て人「製品及グリュンバルサムの反應試驗を置き六項としてコロホニウムの試驗

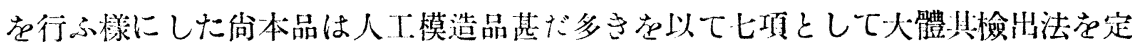
めたのである.

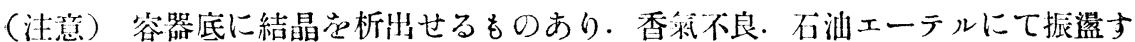
るに粉狀物を沈底す.

Barbitalum バルビタール

從來のヂェチールバルビッール酸兒ちヴエロナールと同筫のもので新たに此名

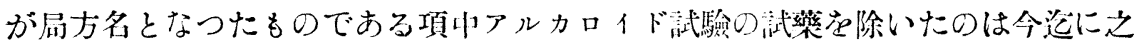
にアルカロイドを以て篇和せるもの佲となきに由る.

（注意）エーテル $(1+50)$ に清浴せす, 焪融點低し.

Balsamum tolutanum トルーバルサム

四項熱アルコール其他に殆と澄明に浴解となしたるは冷アルコールには多と溶 解せす其他の溶解にも澄明には浴けないからである五项新加は實幽反應にして本

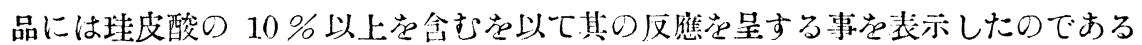
六項改正は從來の方法には樹脂，コロホニウムの反隹不銃做なるを以てなり．

（注意）蓺アルコール $(1+5)$ クロロホルム $(1+5)$ カリ㵽液 $(1+5)$ に溶解の 狀不良.

Balbitalum solubile 溶性バルビタール

之はヂエチールバビッール酸のナトリウム籃でバルビタールは水に難溶なるに 反し甚げ可溶性であるので水藥として與ふるに適賞なるもの一項は性狀にして溶 液はアルカリ性なり二項三項四項五項は其賽性反應で公項七项は夾雜不純物の試 
驗八項はバルビタールの定量で卜分定規䜿酸を $9.8 \mathrm{cc}$ 沙費すると溶性バルビター ルが 100.2\%の計侨で 9.3ce では此品の 95.8\%に相當するものであるつまり此 \%以上の純度觉規定したのである。

Barimu sulfuricum 硫酸バリウム

之も新收载士としてレントゲン使朋の祭の造影冈服劑である之究冈服する分量

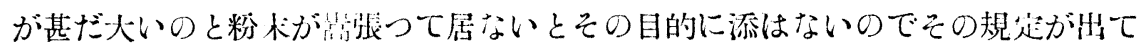

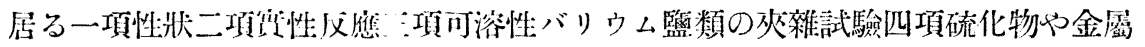

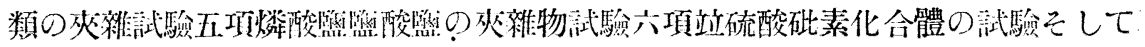
七项がその粉末の異の武驗である。

$$
\text { Benzinum Petrolei 石油ベンジン }
$$

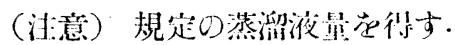

Beta-Naphtholum ベタナフトール

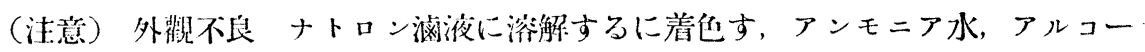
ルに溶解の爿不良.

$$
\text { Bismutum oxyjodogallicum 次沒食子酸ヨード荅鉣 }
$$

一項アルコールと其に拢蕰するとアルコールガ赤色になる事を加へ四項に實性

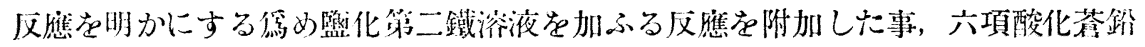

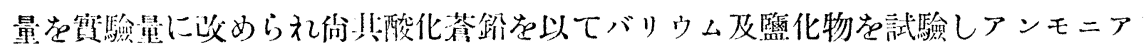

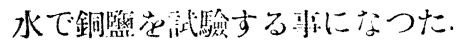

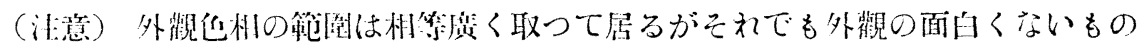
がある文㭙によつて洒性反應が著しいるのがある。

\section{Bismutum subcarbonicum 次炭酸苓䤾}

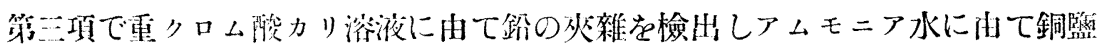

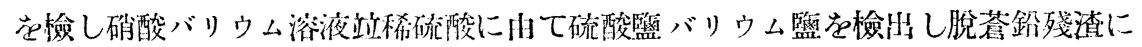
就て莜酸アンモン浴液に由て石炎を檢し最後に除荅鉛液を蒸發熱灼して重量に山 てマグネシアやアルカリ類范檢する事になつた。

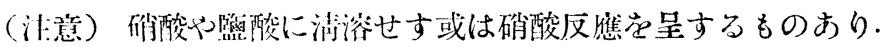

Bismutum subnitricum 次硝酸芩鉛

四版には製法を舉げてあつたが他の苍鈖監類にないので㴊除され四項に石灰の 武驥在加へた。 
（注意） 亞硝酸の臭氣を發するものあり 120 倍檢鏡するに絬晶形泣に大さ區々な ることあり硝酸に溶解するに塵埃多し稀硫酸に溶解するに溷濁す。

Bismutum subsalicylicum 炊サリチル酸荅鈿

四項に石灰の試驗芝加へた.

（注意）硝酸反應著明.

Bolus alba 由陶上

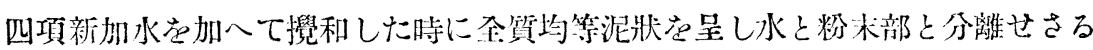
事となつた。

\section{Borax 硼砂}

從來の規定の外向确酸夾雜の試驗が入つた.

（注意） 沸湯 $(1+5)$ に淸溶せ和.

Bromdiaethylacetylurea ブロムヂエチル，アセチル尿素

新加品でアダリンと同質一項性狀二項實性反應三項性及硫酸の弐驗である.

Bromvalerylurea ブロムワレリル尿素

新加嬊でブロムラール，カルモチン管と同質藥である第一项性期二項賽性反應 四項不純有機物五項ブロムの定量試驗である.

Calcaria chlorata 際粉

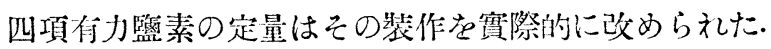

(注意) 付力監素の含量不足，

Calcium carbonicum praecipitatum 沈降炭酸石灰

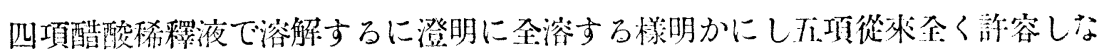
かつた鐵の反應が或程度寬容された。

(注意）醋酸に清溶しないことあり.

Calcium glycerino-phosphoricum. グリ七口燐酸石灰

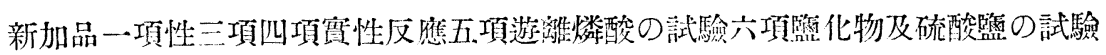

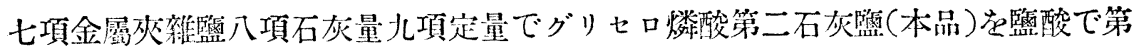

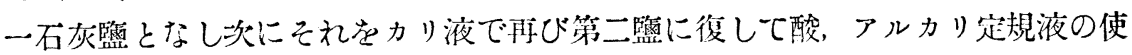
用量等しきや否やを試するので純粹であれば等しかるべき理に由りでの純度を 檢定するのである.

$2\left[\mathrm{CH}_{2}(\mathrm{OH}) \cdot \mathrm{CH}(\mathrm{OH}) \cdot \mathrm{CH}_{2}\left(\mathrm{OPO}_{3} \mathrm{Ca}\right)\right]+2 \mathrm{HCl}=\mathrm{CaCl}_{2}+\left[\mathrm{CH}_{2}(\mathrm{OH}) \cdot \mathrm{CH}(\mathrm{OH}) \cdot \mathrm{CH}_{2}\left(\mathrm{OP}_{3} \mathrm{H}\right)\right]_{2}$

$\mathrm{Ca}$

$\left[\mathrm{CH}_{2}(\mathrm{OH}) \cdot \mathrm{CH}(\mathrm{OH}) \cdot \mathrm{CH}_{2}\left(\mathrm{OPO}_{3} \mathrm{HI}\right) \mathrm{Ca}+2 \mathrm{KOH}=\mathrm{CH}_{2}(\mathrm{OH}) \cdot \mathrm{CH}(\mathrm{OII}) \cdot \mathrm{CH}_{2}\left(\mathrm{OPO}_{3} \mathrm{Ca}\right)\right.$ 
$+\mathrm{CH}_{2}(\mathrm{OH}) \cdot \mathrm{CH}(\mathrm{OH}) \cdot \mathrm{CH}_{2} \mathrm{OPO}_{3} \mathrm{~K}_{2}$

Calcium hypophosphorosum 次亞燐酸石灰

諸種の試驗に内て起万濁度に明かな制限がなかつたのでこの溷濁度の程度が規 定さ补た。

(注意)水に㵋解するに溷渴す然し:項の通り $(1+19)$ の水浴液が蛋白石濁より弱 けれてばよし.

(alcium lacticum 乳酸石灰

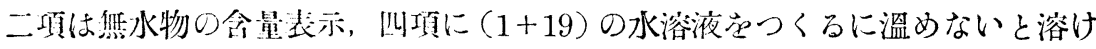
ないものが多いので加溫して浴してもいい㥞になつた六項硝酸銀液に由る寬容は

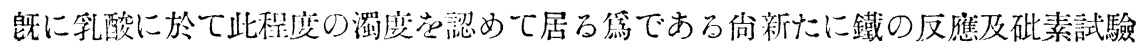
が加はり乾燥減失量の测定は從來 $120^{\circ}$ で行はれて居たがその必要ないので $100^{2}$ に於て施行する事になつた。

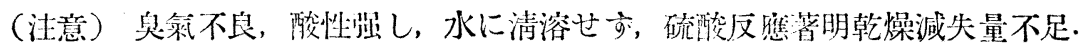

Camphora depurata カンフル

三項に䔖蔽性クロルの茑驗が加はつた。

（注意）旋光性不足.

Camphora monobromata ブロムカンフル

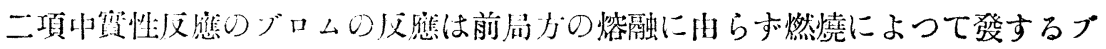
口ム在捉八て胃る柬になつた

（注意）エーテル。 クロロホムに淍浴せず.

Cap:ulae gelatinosae カプセル

膠琵范カプセルと稃する事になり製造の際にゼラチンの外グリセリンや白糖が

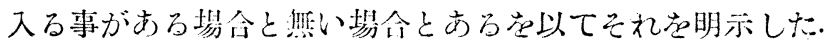

（注意）溫湯に溶解の状不良。

Carbo medicinalis 藥用炭

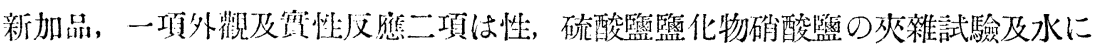

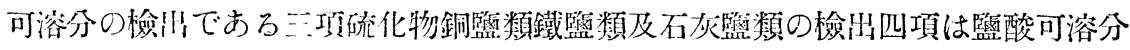
五項は未炭化物六項シアン化合物七項 $120^{\circ}$ に於ける乾燥減失量八項燃化殘留物 の檢出九项及十項は本品の吸着試驗にして前者はメチレン青浴液で色素の吸着力

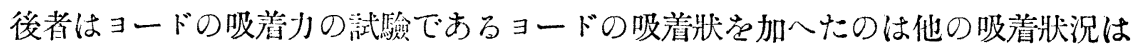
メチレン青と同㥞平行して居らがョードの吸着は實際上他のものと本行性に行か ない第である.

Carboneum tetrachloratum 四盬化炭素

新加品, 一项外觀性狀二项實性反應三項性及監化物の檢出四項遊離クロル五項 溶入の不純油性物質六項不揮發性物質七項クロロホルム檢出八項異種クロル化合 物义は有機性不純物儿項硫化炭素の夾雜試驗である. 
Caseinum カゼイン

新加品, 現在治瘵藥としては使用されては居ない樣だが試藥として例へばバン クレアチンの蛋白質消化試驗等に相當純粹なものが必要な䉆め此の規定として加 入されたものである一項外觀性狀及性，二項賽性汉篗 項燐化合體としての賽性 反應四項アルカリに不溶の不純分五項アルカリ性不純分水に可溶不純分の檢州六 項脂肪分の檢出七項水分及灰分の檢出である.

Cautschuc 精製パラゴム

彈力ゴムと秎したものを明らかにパラゴムとしたもの閩科をまとめて Hevea 屬と一活した三項石油心゙ンヂンに溶解するに潑明液となる事殆に゙なし故に溷濁液 を涊め不溶物を遺さぬ事に改めた五項にア七トン没壮液に就て樹脂分の夾雜を限 定した。

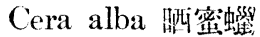

前局方の白䗒であるエステル數 77.6-93.5 に改めたるは賈驗上純品と認むべき

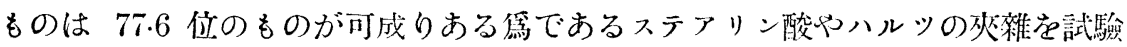

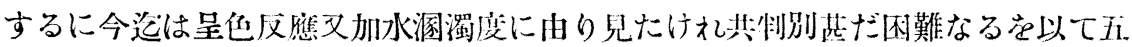
項の如く限定されてた。

(注意) エステル數過多.

\section{Cera flava 蜜蛉}

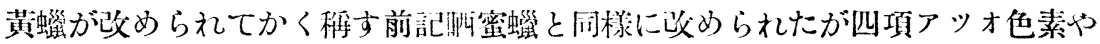

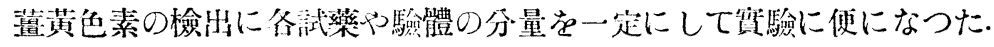

（沬意）エステル數過多.

Cerium oxalicum 㜔酸七リウム

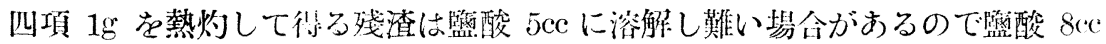

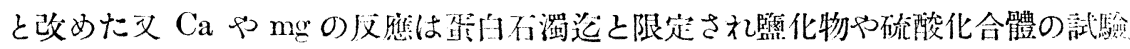
は寬容しない事に改まつた。

（注意）艦酸に溶解の狀不良.

Calcium phosphoricum praecipitatum 沈隆燐酸石灰

（汢意）鹽酸に溶解するに着色す, 硫酸の反隹著明, 熱灼減量少し.

Chininum aethylcarbonicum エチル炭酸キニーネ

四項硫酸站監酸反應を硝酸性水溶液 $(1+49)$ の稀瑇液となつたのは前の $(1+19)$ 浴液は淸溶しない事が往々ある篇である.

（注意）エーテル，クロロホルムに清溶せず, 确酸性水浴液は溷渴军.

Chininum hydrochloricum 鹽酸キニーネ

（注意）純アルコールクロロホルムの混液に清溶せず, アルコールに溶解の狀不 良, 硫酸の反應强し, ケルネル數高し. 
Chininum sulfuricum 硫酸キニーネ

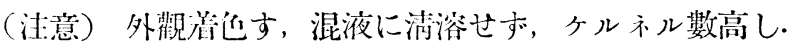

Chloralum hydratum 抱水クロラール

斑項クロラールアルコホラートの武驗は從來の方法は亞硝酸を析出して黄色カ

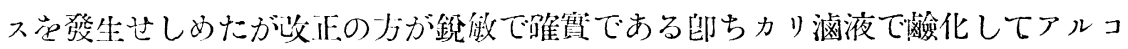
ールを生しョードによりてョードホルム冢生ずる。

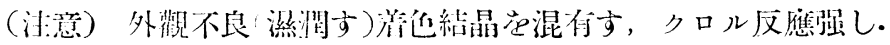

Chloraminum クロラ

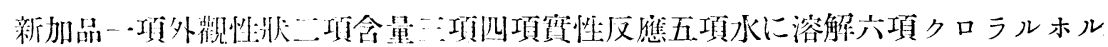

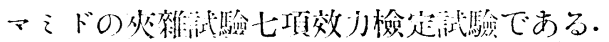

$$
\begin{gathered}
\text { ( } \mathrm{II}_{3} \cdot \mathrm{C}_{6} \mathrm{I}_{4} \cdot \mathrm{SO}_{2} \mathrm{~N}<\mathrm{Cl}+\mathrm{H}_{2} \mathrm{O}=\mathrm{CH}_{3} \cdot \mathrm{C}_{6} \mathrm{H}_{4} \cdot \mathrm{SO}_{2} \mathrm{NH}_{2}+\mathrm{NaOCl} \\
\mathrm{NaOCl}+2 \mathrm{HIJ}=2 \mathrm{~J}+\mathrm{H}_{2} \mathrm{O}+\mathrm{NaCl} \\
\text { Chloroformium クロロホルム }
\end{gathered}
$$

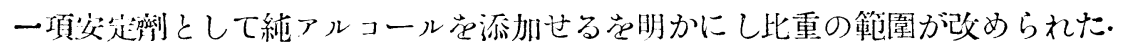

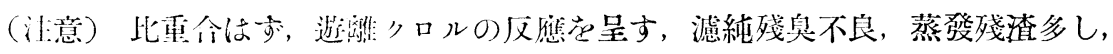
硫酸と振湿するに染们す。

Chloroformium pro narcosi 触醉用クロロホルム

五項ヂメチルアネノアゾベンゾールを朋ひて鹽酸の反應を檢する項が新たに加

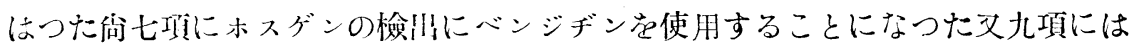

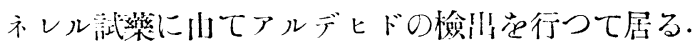

(i等) クロロホルムと间じ.

$$
\text { Chryarobinum クリサロビン }
$$

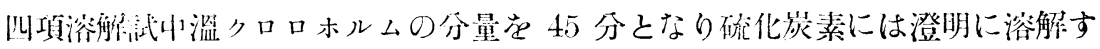

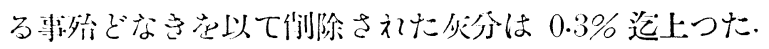

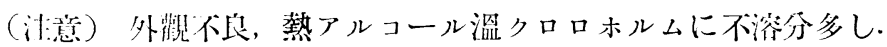

Cocainum hydrochloricum 鹽化コカイン

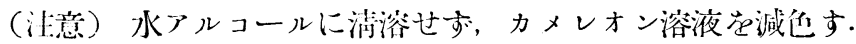

Codeinum phosphoricum 燐酸コデイン

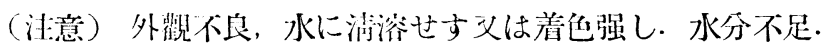

\section{日本藥局方藥品滴數表}

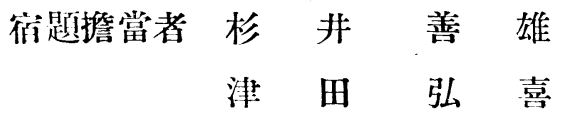




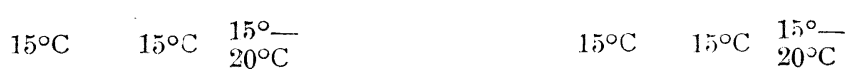

\begin{tabular}{|c|c|c|c|c|c|c|c|c|c|}
\hline 藥 & 滴 & & 重 & & 藥 品 & & & 重 & 面 \\
\hline t & $66^{\text {ptt }}$ & $15^{g}$ & & & 石 油 & $81^{\text {git }}$ & $12^{g}$ & & \\
\hline 酸 & 34 & 0.030 & 1.044 & 52.97 & よ゙ンジール & 54 & 018 & 882 & 5.89 \\
\hline 酸 & 2 & 10 & & 32 & 四塩化岸素 & 62 & 016 & 05 & 3.06 \\
\hline 酸 & & 18 & & & ク口只木ル & 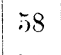 & 017 & 88 & 4.60 \\
\hline 酸 & 21 & 49 & 3 & .88 & 麻醉用クロロホルム & 58 & 0.017 & 459 & 34.26 \\
\hline 酸 & 21 & 48 & 1 & 69.82 & $=>\eta$ & 51 & 0.020 & 0.9405 & 28.94 \\
\hline 酸 & & & & 03 & コロヂオン & 71 & 0.014 & 00 & 27.26 \\
\hline 酸 & 22 & 46 & 3 & 64.16 & カンタツスコロ无れン & 4 & 0.016 & 8 & $29.0^{2}$ \\
\hline 發 煙 硝 酸 & 33 & 30 & & - & 彈力コロヂネン & 66 & 0.015 & 02 & 28.25 \\
\hline オ $21 ン$ 酸 & 4 & & & 37.86 & 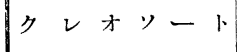 & 39 & 0.0255 & 84 & 45.2 \\
\hline 酸 & 2 & & & 85 & 粗制クレゾール & 42 & 24 & 10 & 41.4 \\
\hline 酸 & 28 & 36 & 10 & 64.88 & キナ流䡃エキス & 58 & 017 & 010 & 33.9 \\
\hline 酸 & 20 & 60 & 1 & 72.73 & 動轮 & 41 & .025 & 032 & $44.8 !$ \\
\hline$-\quad \bar{r}$ & 89 & 0.011 & 722 & 22.24 & & 57 & 017 & 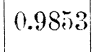 & 33.8 \\
\hline 醋酸エチル & 63 & 0.016 & 9050 & 30.00 & & 40 & 025 & 1.044 & 42. \\
\hline 㭽醉用エーテル & 86 & 12 & 20 & 22.24 & 麥角流動エキス & 41 & 0.024 & 53 & 45.1 \\
\hline$>ル z-u$ & 64 & 0.016 & 24 & 30.05 & ホ & 30 & 33 & & 55.6 \\
\hline 純 アルコール & 69 & 4 & 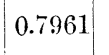 & 27.65 & $\begin{array}{lllll}ク ゙ & y & セ & y & \text { V }\end{array}$ & 22 & 5 & & 72. \\
\hline 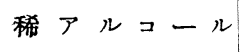 & 56 & 18 & 8940 & 33.66 & クエン酸りモナーデ & 19 & 0.052 & 11 & 64.8 \\
\hline 亞㗂酸 $ア ミ 儿$ & 72 & 014 & 8829 & 27.81 & 壏酸りモナーデ & 20 & .051 & 28 & 75.3 \\
\hline $\boldsymbol{P}=\epsilon=\Gamma$ 水 & 23 & 4 & 99 & 62.40 & ミニウム滩 & 21 & 47 & .038 & 57. \\
\hline た & 37 & 27 & 75 & 46.27 & モン 液 & 20 & 050 & 1.034 & 77.2 \\
\hline 灰 & 20 & 050 & & 0.23 & 滩 & 18 & 56 & & 91. \\
\hline 桂 & 2 & & 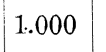 & 5.89 & 儉液 & $4 i$ & 22 & & $39.6 t$ \\
\hline & 20 & 050 & 000 & 78.48 & 壗酸工 & 25 & .039 & .019 & 66.1 \\
\hline ゾー & 50 & 020 & 1.0 & 47 & $y x$ & 21 & .048 & 260 & 5.7 \\
\hline 溜 & 20 & 50 & $1 .($ & .48 & 液 & 14 & 056 & & 80.9 \\
\hline 花 & 27 & 37 & 1. & 62 & 滩 & 2 & 0.050 & 430 & 85.2 \\
\hline 茴 & 21 & 47 & 1.00 & .76 & グッタペルカ液 & 57 & 0.018 & $4 \angle 0$ & 37.86 \\
\hline 小 $ル マ リ$ & 21 & 0.048 & 1.0 & 76.61 & 過酸化水素水 & 20 & 0.049 & 1.01 & 76.9 \\
\hline 溥 & 29 & 0.035 & 1.0 & .00 & 力 リ 澅 液 & 19 & 0.05 & 1.140 & 66. \\
\hline 石崖酸水 & 28 & 0.036 & 1.0 & 7.09 & グリセリンカリ液 & 43 & 023 & 015 & 2.0 \\
\hline 壏酸加石炭酸水 & 34 & 0.030 & & 99 & 醋酸カリ液 & 27 & 0.037 & 1.180 & 4.8 \\
\hline 防选用石崖酸水 & 31 & 0.033 & & 3.74 & 亞 砒酸力り液 & 34 & 0.029 & 996 & 50. \\
\hline 一 ズ 水 & 25 & 0.040 & 1.0 & 56.79 & 口 \% ク 液 & 20 & 0.05 & 1.009 & 3. \\
\hline ベンズアル & 38 & 0.026 & 1.050 & 47.14 & ゴール 液 & 21 & 0.048 & 1.084 & 70.8 \\
\hline
\end{tabular}




\begin{tabular}{|c|c|c|c|c|c|c|c|c|c|}
\hline & & & & & • ’ & & & & \\
\hline$i$ & 21 & 0.048 & 0 & 78.38 & シロップ & & 0.0 .50 & & \\
\hline & 20 & 50 & & & 䓢蜀葵シロップ & & & & \\
\hline . & 20 & & & & シロッ & & & & \\
\hline 花 生 & 42 & & & & 渮シロップ & & & & \\
\hline 伝 & 44 & & & & シ シ & & & & \\
\hline 花 & 54 & & & & 大黃 シロッ プ & 1 & & & \\
\hline ン ジ 油 & 53 & & & & ニネガシロップ & 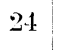 & & & \\
\hline ガモット泪 & 52 & & & & センナシロップ & : & & 8 & \\
\hline$ヤ フ^{\circ} テ$ & 52 & & & & 口 \% プ & & & & \\
\hline & 43 & & & & 生譡シロップ & & & & \\
\hline & 44 & & & & エ 一テル精 & & & & \\
\hline & 45 & & & & 甘 & & & & \\
\hline ノポヂ & 49 & & & & & & & & \\
\hline : & 50 & 20 & & & $r$ & & & & \\
\hline & 43 & 3 & & & 香 & & & & \\
\hline 油 & 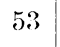 & 0 & & & ンフル精 & 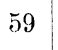 & & & \\
\hline トロネラ油 & 5 & & & & クロロホルム精 & & & & \\
\hline & 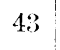 & & & & 桂 & & & & \\
\hline カ & ; & & & & 精 & & & & \\
\hline 袚 & 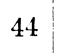 & & & & & & & & \\
\hline & 44 & & & & $\exists-ト ゙ f$ & 61 & & & \\
\hline ヘンンデ & . & & & & チンキ & 66 & & & \\
\hline (s) & 43 & $0^{\prime}$ & & & ラ ヘ ン & 5 & & & \\
\hline 油 & 58 & & 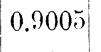 & & 灌 & 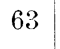 & & & \\
\hline 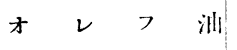 & & & & & ロスマリン精 & & & & \\
\hline$\checkmark \quad$ シ 油 & n & & & & 石 & & & & \\
\hline 一 ズ 油 $30^{\circ}$ & j & & & & & & & & \\
\hline ス $>$ リ & 54 & & & & 727 & 3 & & & \\
\hline 㥀 & 39 & & & & 味チンキ & & & & \\
\hline 梳 & 42 & & & & 香 チンキ & & & & \\
\hline 芥子洲 & 45 & & & & ・ チン キ & & & & \\
\hline 표. & 4 & & & & 皮チンキ & & & & \\
\hline レビン 油 & 5 & & & & 安息香チンキ & & & & \\
\hline & 56 & & & & チンキ & & & & \\
\hline s $ア ン$ 油 & 51 & & & & & & & & \\
\hline$a_{1}=-x$ & 45 & 22 & & & 蕃 椒 チンキ & & & & \\
\hline 万残酸 & 37 & & & & 阿 仙 薬チンキ & & & & \\
\hline & 35 & 0.029 & & & : & & & & 然 \\
\hline & 28 & 0.036 & 272 & 58.89 & チンキ & 5 & $01 \varepsilon$ & 914 & 5 \\
\hline
\end{tabular}




\begin{tabular}{|c|c|c|c|c|c|c|c|c|c|}
\hline 桂皮チンキ & 56 & 0.018 & 0.894 & 33.29 & 大笽チンキ & 51 & 0.019 & 0.956 & 36.66 \\
\hline コロンボチンキ & 57 & 0.018 & 0.894 & 33.36 & 水性大黃チンキ & 29 & 0.085 & 1.012 & 57.09 \\
\hline サフランチンキ & 55 & 0.018 & 0.916 & 33.66 & ロートチンキ & 57 & 0.018 & 0.912 & 23.98 \\
\hline ヂギタリスチンキ & 55 & 0.018 & 0.907 & 33.66 & ストロフアンツスキンク & 57 & 0.618 & 0.895 & 31.90 \\
\hline リンゴ鉄チンキ & 38 & 0.026 & 1.009 & 45.08 & ホミカチンキ & 57 & 0.018 & 0.966 & 30.06 \\
\hline 五倍子チンキ & 57 & 0.018 & 0.950 & 33.66 & 吉 苦チンキ & 56 & 0.018 & 0.960 & 31.8 .4 \\
\hline ゲンチアナチンキ & 56 & 0.018 & 0.918 & 38.66 & メーラル性吉苦チンキ & 66 & 0.015 & 0.814 & 28.2 .5 \\
\hline グアヤクチンキ & 63 & 0.016 & $0.8 \check{0} 0$ & 31.81 & 生薑チンキ & of & 0.018 & 0.908 & 3.066 \\
\hline 哑 根チンキ & 57 & 0.017 & 0.913 & 33.66 & 楕 & $: 32$ & 0.082 & 0.9945 & $5+69$ \\
\hline ミルラチンキ & 63 & 0.016 & 0.854 & 30.20 & 濉 & 33 & 0.0 .81 & 1.0507 & 56.92 \\
\hline 阿 片チンキ & 40 & 0.022 & 0.980 & 40.27 & コンヅランゴ酒 & 32 & 0.031 & 1.0317 & 43.25 \\
\hline 阿片安息香チンキ & 56 & 0.018 & 0.901 & 34.26 & & $: 1$ & 0.032 & 1.0196 & 54.49 \\
\hline 苦木チンキ & 57 & 0.018 & 0.892 & 35.22 & ペ プシン 汧 & 30 & 0.083 & 1.0323 & 54.09 \\
\hline
\end{tabular}

